\title{
A aventura de fazer cinema no Amazonas
}

\author{
Entrevista e homenagem a Cosme Alves Netto
}

No filme "Bye Bye Brasil", de Carlos Diegues, o mágico, já no final do filme, conversando com o sanfoneiro, comenta o quanto eles eram ignorantes, no começo, quando exibiam o nome "Caravana Rolidei" no caminhão que os transportava. Passaram-se os anos, cada um foi para o seu lado e foi nesse processo que o mágico descobriu a grafia correta: "Holiday".

- Como a gente era ignorante!

Esta cena se repetiu em Manaus, na memorável noite de 22 de janeiro de 1986, quando na residência do empresário Nuno Cunha reuniu-se um grupo de pessoas envolvidas com cinema no Amazonas desde o início dos anos 60. A simples presença do então diretor da Cinemateca do Museu de Arte Moderna do Rio de Janeiro, Cosme Alves Netto [que viria a falecer 10 anos depois], foi suficiente para a aglutinação de pessoas como Ivens Lima e Joaquim Marinho. Explica-se: ao lado de Cosme, eles agitaram, através de programas radiofônicos, críticas de jornais, cineclubes e festivais, talvez o mais importante movimento em torno do cinema no Amazonas.

O mais curioso, todavia, é que eles desconheciam, na época, a figura do grande pioneiro Silvino Santos. Achavam até mesmo que estavam inventando cinema no Amazonas, como afirma Cosme:

"Na verdade, nós não estávamos inventando o cinema no Amazonas, como pensávamos, pois o cinema já existia aqui desde a década de dez e não sabíamos. O mais impressionante é que não existiu só Silvino Santos, como depois a gente veio a descobrir".

Na verdade, a Amazônia já havia sido penetrada pela câmara de dezenas de pioneiros, brasileiros e estrangeiros. O que destaca Silvino é o fato de ter ficado em Manaus e aqui realizado a sua obra, uma obra tão grande e rica como o rio das Amazonas, um de seus grandes temas.

Participaram desta entrevista, ainda, os professores e pesquisadores de cinema Selda Vale da Costa e Narciso Júlio Freire Lobo, que conduziram a entrevista, e o professor Antonio Paulo Graça [já falecido], da Universidade do Amazonas.

Pois é, agora não somos mais tão ignorantes, pelo menos com relação ao nosso passado no campo cinematográfico. No entanto, este bate-papo descontraído traz à tona questões cruciais relacionadas com o cinema e a preservação da memória amazonense. Corremos o perigo de esquecer tudo se todo o trabalho de descoberta,

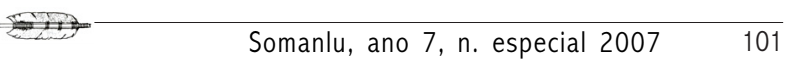


realizado até agora, continuar sendo obstaculizado. Aqui estão algumas propostas para que o Amazonas volte a produzir cultura cinematográfica.

Narciso Júlio Freire Lobo

Narciso - Estamos aqui com o Ivens Lima, o Joaquim Marinho e o Cosme Alves Netto, pessoas do cinema na década de 50, 60.

Marinho - 70 e 80.

Narciso - ...70 e 80, e vamos bater um papo sobre cinema no Amazonas.

Marinho - Vamos lá. Eu acho que tudo aquilo começou com a vinda daquele padre amigo teu (do Cosme) até aqui. Foi mais ou menos isso, Ivens? Tu tens idéia! Solta tu a primeira parte, que é melhor pra gente depois coordenar essas idéias.

Ivens - Não, eu acho que a coisa começou por volta de 1962, quando eu fui procurado pelo Cosme. Àquela altura eu trabalhava na Rádio Rio Mar fazendo um programa chamado Cinemascope no ar. Aí, o Cosme me procurou porque ele tinha um objetivo, ele queria lançar inicialmente um curso de cinema, uma tentativa de reunir pessoas interessadas. Então, através do meu programa, ele fez um contato direto. Nós não nos conhecíamos pessoalmente, mas ele fez um convite: se eu estaria disposto a participar e apoiar a iniciativa dele. Eu disse: “tá bom”. Então, lá numa das salas do Teatro Amazonas...

Cosme-Exatamente.

Ivens - ... às 18 horas, duas ou três vezes por semana.

Cosme - É, eu não me lembro se nessa época era o Nivaldo (Santiago) que era o diretor do Teatro ou ...

Ivens - Não, não era... Aí, o Cosme criou o curso, deu divulgação à coisa e a sala encheu. Apareceram os participantes. Modestamente, eu apoiei e levei outro amigo nosso, que no meu entender é um cara que merece todo respeito, chamado Albertino Jorge da Silva, que, apesar de não ser intelectual pela parte histórica, é, eu o considero, um intelectual pela parte inventiva e técnica da coisa.

Marinho - Onde está o Zé Alberto? ${ }^{1}$

Cosme - Eu me lembro que nessa época apareceu também uma outra pessoa igualmente fantástica, chamada Guanabara de Araújo.

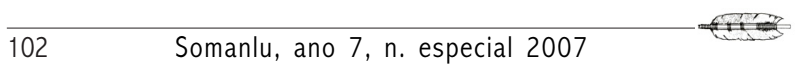



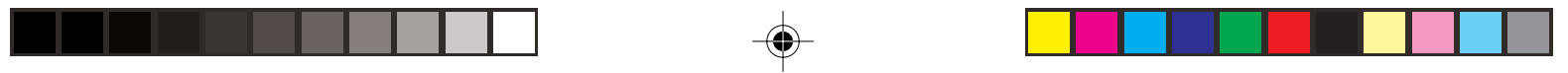

Cosme Alves Netto

Marinho - Guanabara de Araújo, que foi presidente do GEC.

Ivens - E nesse curso, então, nós tivemos a oportunidade, enquanto o Cosme nos ministrava as aulas de história e técnicas do cinema, nós tomávamos contato com o pe. Ruas, que era quem ministrava as aulas sobre estética cinematográfica.

Marinho - Exato. Aí é que surgiu o tal seminário, o que foi feito no Teatro Amazonas. Não houve um seminário? Foi a partir daí que surgiu a idéia do GEC.

Ivens - Depois desse curso, o Cosme, então, conseguiu que se criasse o Grupo de Estudos Cinematográficos, que é o GEC. O GEC, modestamente, funcionou durante diversos anos, inclusive nos anos mais duros da "briosa", não foi?

Cosme - É. Ressaltando que eu já não estava aqui nessa época, porque aí eu fui embora para o Rio, definitivamente.

Ivens - Bom, mas no grosso da coisa você ainda estava, 62, 63, você ainda estava ... Cosme-É, e foi nesse tempo, inclusive, que apareceu lá um rapaz interessadíssimo em cinema, que era o Márcio Souza.

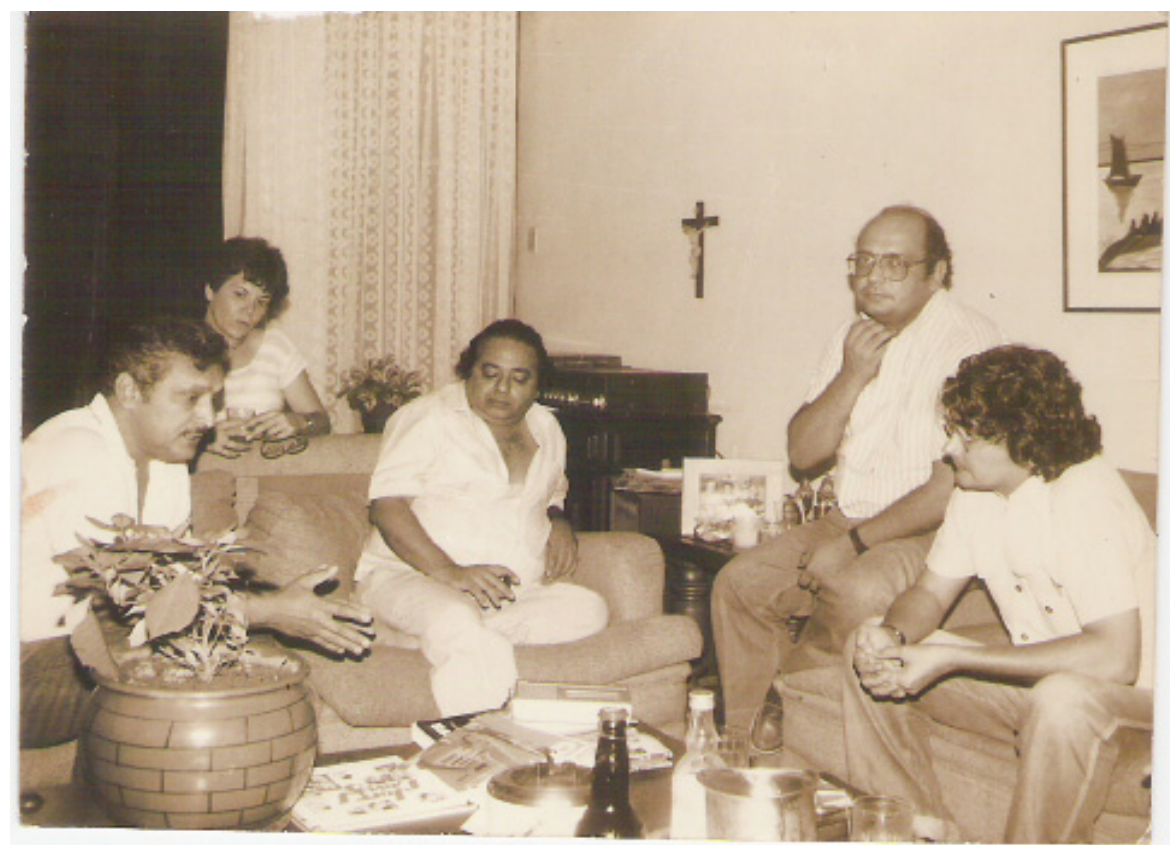

Uma data histórica: Manaus. 22 de janeiro de 1986. Da esq. para dir.: Ivens Lima, Selda Vale da Costa, Cosme Alves Netto, Joaquim Marinho e Narciso Lobo, reconstituindo a memória cinematográfica amazonense (Acervo de Selda V. da Costa) 
Ivens - O Márcio Souza apareceu, foi um dos alunos ...

Marinho - O Márcio, o Djalma Batista e o irmão dele, o Gualter.

Nuno - Não foi nessa época, antes de você ir para o Rio, que você exibiu lá o "Encouraçado Potemkin"?

Marinho - Não, isso aí já foi lá no Cineclube do DER-AM. Peraí, isso aí já é parte histórica, disso aí já se tem memória histórica ...

Ivens - Com o desenvolvimento...

Narciso - O rádio era muito forte ...

Marinho-É, fortíssimo. O Ivens tinha um programa que era um colosso.

Narciso - Pela parte da imprensa também havia ...

Marinho - Havia coluna de cinema também. Eu fazia a página de cinema no "Diário da Tarde".

Ivens - A parte de rádio estava entregue aos meus cuidados, pela Rádio Rio Mar, no programa Cinemascope no ar, aos domingos.

Marinho - Tu fazias o Cinemascope no ar antes de 60, não é?

Ivens - Eu fiz Cinemascope no ar desde 1954, desde a fundação da Rádio Rio Mar. Marinho - Exato.

\section{"Quem é esse Ivens Lima que está aqui falando sobre cinema em Manaus, onde ninguém está interessado em cinema?"}

Ivens - O Cosme, nas vezes que vinha a Manaus, sempre ouvia o programa, porque era aos domingos, das 8 até às 9 da manhã, certo? E eu tinha um "slogan".... Dizia assim: "O cinema em sua casa". Eu consegui o máximo naquela altura, que era gravar a pista sonora dos "trailers", do que ia ser lançado na semana seguinte e eu apresentava. Dizia: "Atenção, que nós vamos passar agora o que você vai ver pra semana..."

Marinho - Dentro do cinema, na caixa de som do cinema... Botava o "trailer" no ar!

Ivens - O "trailer" da semana. Então, eu passava só a parte sonora.

Marinho - Era o videoclipe daquela época. Era o radioclip...

Selda - Como a novela de rádio, não é?

Ivens - É, a novela de rádio...

104 Somanlu, ano 7, n. especial 2007 
Narciso - Era em inglês e aí ele traduzia...

Ivens - Eu fazia uma outra coisa, fazia dublagem, não é? Em cima do que eu via na tela, eu lia aquele troço. O Moraes, que trabalha com o Marinho, ligava a máquina e eu tinha aquilo à minha inteira disposição. Os proprietários de cinema me facilitavam. Tanta era a força que nós tínhamos na mão, que o Cosme sentiu o negócio e me chamou. Eu disse: "Vamos lá, vamos lá."

Cosme -É, porque aí eu escutava esse negócio no rádio e dizia: “Quem é esse Ivens Lima, esse maluco que está aqui falando sobre cinema, em Manaus, onde ninguém está interessado em cinema?” e aí eu fui procurar o Ivens. Foi aí que eu conheci o Ivens. Eu morava já no Rio, mas vinha sempre passar as férias em Manaus. Eu era interno lá no São José, num colégio do Rio e vinha passar as férias aqui. Foi aí que entrei em contato com o Ivens. Na verdade, digamos que o período que nós estamos vivendo até hoje começou com o programa do Ivens.

Narciso - Vocês transavam cinema pra organizar politicamente as pessoas, ou...

Marinho - Não. Nós éramos tarados por cinema, tarados por cinema.

Cosme - Nós éramos o que somos hoje, cinéfilos. Na verdade, nós somos cinéfilos até hoje.

Narciso - E não havia também da parte de vocês nenhuma perspectiva de realização, não é isso? Era apenas vontade de fazer...

Marinho - Ah, de fazer cinema, não, de produzir filme, não.

Cosme - Nosso interesse era ver o filme e curtir filmes.

Marinho - Encucação cinematográfica.

Ivens - Agora vai um adendo muito importante. Um dia, o Cosme disse assim: "Nós precisamos testar e ver a força do Grupo de Estudos Cinematográficos", que era um embrião. Então, nós conseguimos uma loucura. Nós conseguimos o auditório do Palácio Rodoviário na Cachoeirinha e organizamos um programa, mas um programa de impacto. Convidamos praticamente a cidade inteira, não foi, Cosme? E pessoas eruditas... Inclusive, naquela altura, até o comendador Agesilau de Araújo, que era considerado um bom "papo", gostava de cinema, um dos pioneiros de cinema aqui em Manaus...

Cosme - Ressaltando que naquela época a gente não tinha a menor idéia de quem era Silvino Santos.

Marinho - Não, ninguém sabia nada. Ninguém sabia que existia nada. Isso só veio aparecer em 67. 
Selda e Narciso - Em 69.

Ivens - Ninguém sabia nada. Nós estávamos começando, vivendo, abrindo caminho para tentar mostrar...

Cosme - O que a gente discutia mesmo era cinema estrangeiro.

Marinho-Certo.

Ivens - Bom, então o Cosme organizou um programa onde se projetou "Le bateau" e se viu, pela primeira vez, Norman McLaren, num auditório de 400 lugares que, nessa noite, deu pra mais de duas mil pessoas.

Marinho - Não, era bem maior aquele auditório...

Ivens - $\mathrm{O}$ auditório do Palácio Rodoviário estava superlotado. Todo povo da Cachoeirinha, da cidade, acorreu pra aquele local e eles ficaram extasiados, porque, pela primeira em Manaus, eu acho, se viu um tipo de cinema diferente. Foi um impacto tamanho, uma coisa de maluco.

Marinho - Imagina, foi "Vizinhos", de McLaren que ele passou...

Ivens - Foi, passou "Vizinhos", de McLaren, "A galinha”, de McLaren, "A marcha das cores", de Len-Lye, "Le bateau”, do Marcel Marceau, com sua mímica...

Cosme-Geniais...

Ivens - Daí, através dessa sessão, o impacto foi tamanho que começaram a aparecer pessoas. Por exemplo, apareceu Joaquim Marinho, apareceu o Guanabara de Araújo. Nós tínhamos umas sessões particulares lá na minha casa. O GEC funcionou durante muitos anos na casa do meu pai, na Getúlio Vargas, 1003, em frente de onde hoje em dia é a Telamazon ${ }^{2}$. Então, uma noite, nós estávamos programados lá para ter uma sessão. O Cosme, às 7 da noite, falou: "Olha, eu encontrei um rapaz que gosta muito de cinema e eu o convidei. Ele pode vir?”. Pode. Então, nessa hora nós ouvimos assim (som de palmas) no portão. Aí fomos lá e descobrimos uma figura que até hoje é inconfundível, que é o nosso prezado amigo José Gaspar.

Marinho - Zé Gaspaire (risada geral).

Ivens - Zé Gaspar. E ele com suas opiniões, não é?

Cosme - Depois é preciso fazer a copidescagem da entrevista...

Ivens - Era o único salazarista-comunista do mundo! (risada geral)

Marinho - Era o único comunista-salazarista do mundo, não é? E nascido na Rua dos Barés, o que é mais importante ainda. É, nascido na Rua dos Barés...

Ivens - Com sotaque português até hoje.

Marinho-É, com sotaque português até hoje. Então, é um negócio realmente sui

106 Somanlu, ano 7, n. especial 2007 

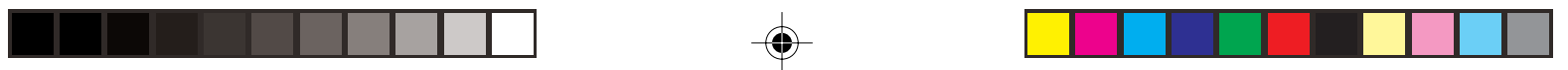

Cosme Alves Netto

generis: salazarista-comunista da Rua dos Barés...

Narciso - ... sem censura...

"No GEC, a gente passava de tudo: Hitchcock, McLaren, René Clair, Einsenstein, filme de bang-bang, cinema fantástico..."

Ivens - Após essas primeiras movimentações, esses primeiros contatos, essas primeiras sessões, então, o Cosme começou realmente a nos mostrar um outro lado do cinema. Até aquela altura, tudo era novidade. O camarada fazia porque tinha vontade de fazer. Ia tocado pelo "bichinho". Então, o Cosme começou a burilar e criar uns negócios diferentes: Ciclos. Então era o Ciclo Hitchcoquiano...

Marinho - ...do cinema fantástico...

Ivens - Ciclo do cinema fantástico, ciclo disso, ciclo daquilo e com isso, você sabe, começou uma nova abertura pra nós, pois nós realmente gostávamos de cinema e começamos a pesquisar. Por outro lado, houve o primeiro toque, se é que podemos dizer assim, de mostrar... a organização e o princípio político do cinema. Foi quando nós começamos a sair daqui, não é, Cosme? Foi uma loucura... O Cosme disse: "Olha, vai haver um congresso de cineclubes lá em Porto Alegre", te lembra?

Cosme - Lembro, o famoso congresso de Porto Alegre (rindo).

Marinho e Cosme - (risos)

Ivens - Famoso congresso! Quando acabou tudo...

[Comentários pouco exemplares sobre o famoso congresso].

Ivens - Então, nós tivemos aí, em 1960..., aquilo foi 62, 63, por aí, mais ou menos, esse encontro... o IV Encontro de Cineclubes de Porto Alegre. Então, eu saí daqui representando o GEC. O GEC não tinha dinheiro, não tinha nada, não é? Eu fui por minha conta, curiosidade em ver... Saí eu, por um lado... e o agora deputado Randolpho Bittencourt, que àquela altura era o presidente do Cineclube Rodoviário. Cosme - O Randolpho tirou o ph do nome. Ficou Randolfo com f. (risadas) Naquele tempo ele era Randolpho com ph. Falando em Randolpho, tem um episódio fantástico, lá em Porto Alegre. Essa é incrível, porque havia um padre, o famoso padre Massotte...

Ivens - Baixinho, de Minas Gerais...

Cosme - Edeimar Massotte. Morreu, não é?

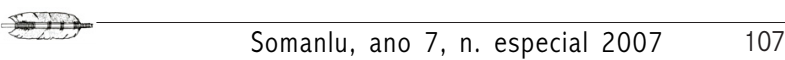


Marinho-Morreu?!

Cosme - Morreu há uns 3 anos atrás. Então, o padre Edeimar Massotte chegou em Porto Alegre representando vinte cineclubes fantasmas... Tinha Cineclube Mickey Mouse, Cineclube Grace Kelly...

Ivens - Grace Kelly! (risada)

Marinho - E Cineclube "Pró Deo"...

Cosme - E tinha o "Pró Deo", de Porto Alegre...

Ivens - Mas, o "Pró Deo" era do Humberto Didonet. Depois ficou maluco e foi internado...

Cosme - Então, esse episódio do Randolpho é fantástico!

Marinho-É. Ele tinha aquela mania de oratória.

Cosme - Ele era orador nato e era o orador do grupo. Então, houve um determinado momento em que a gente tinha que encaminhar contra uma proposta, que eu não me lembro o que era, porque naquele momento a gente já tava ficando politizado, aquele negócio de grupo pra lá e pra cá... Então, o Randolpho tinha que encaminhar um negócio contra, mas ele entendeu mal e achou que era para encaminhar a favor. E não teve dúvidas, mandou brasa, começou a elogiar: porque é uma proposta genial, fantástica, por causa disso, disso e daquilo. Aí, a gente mandou um bilhetinho escrito pra ele: "Randolpho, não é pra ser a favor, é pra ser contra". Ele leu o bilhete e, sem alterar a voz, disse: "Tudo isso que eu disse aqui seria correto se essa proposta fosse boa, mas a proposta é péssima"(riso geral) E arrasou com a proposta, que acabou não sendo aprovada.

Narciso - Sujeito coerente, mesmo!

Cosme - Um tremendo orador, realmente. Ele mudou na hora, no meio da uma frase. Ele leu o bilhete e no meio da frase mudou.

Narciso - Isso no ano eleitoral é uma boa lição!(risos)

Marinho - Isso aí é em "off"...

Selda - Falando em "off”, é verdade que havia uma determinada pessoa no GEC que só apresentava e não fazia mais nada? Só fazia apresentação dos filmes e não sei o quê e depois, ó, se mandava?

Todos - Quem era? Quem era?

Selda - Eu ouvi falar que tinha uma pessoa assim.

Cosme - Mas, quem era? Não me lembro quem era...

Selda - (pigarreando) Humm... Quem tem uma voz, assim de apresentador, radialista,

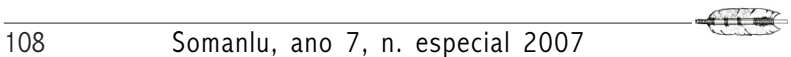


Cosme Alves Netto

de televisão...

Marinho - Todos tinham voz de apresentador. O Ivens tinha, eu tinha... (risadas).

Todos - Era o Marinho!

Marinho (risadas) - Que prestígio eu tinha, não é?

Ivens - Ora, o apresentador oficial era o Joaquim (risos).

Selda - Aquele que chegava na última hora: "O que é pra apresentar mesmo?"

Ivens - O que ocorria era o seguinte: as sessões eram lá no Palácio Rodoviário.

Bom, o Cosme pediu uma camionete emprestada...

Marinho - Ao pai dele, era uma rural Willys...

Ivens - E depois de muito tempo é que eu vim a saber que o Cosme mal sabia dirigir e não tinha carteira...

Marinho (rindo) - Continua igual, continua igual...

Ivens - E todas as noites de sessão íamos, eu e o Albertino, no banco de trás, levando o equipamento e o projetor, que era lá de casa.

Cosme - E o Albertino era o operador. Ele era sempre o operador, ele cuidava da parte técnica. E o Guanabara de Araújo ficava na porta com uma lanterninha (risadas), levando as pessoas pro lugar (gargalhadas).

Marinho - Isso é mentira!

Cosme - Não, é verdade.

Marinho - O Guanabara de Araújo!!! (risadas)

Cosme - O Guanabara... ia sempre com uma lanterna porque ele morava num lugar que não tinha luz, sei lá. Não tinha luz na rua...

Marinho - Manaus naquela época não tinha luz em parte nenhuma.

Cosme - Então, ele sempre saía de casa com uma lanterna e chegava lá com um guarda-chuva...

Marinho - E a realização nossa era que o Palácio Rodoviário tinha gerador e, então, sempre tinha luz, nunca faltava luz.

Ivens - O importante é o seguinte: era um grupo novo, praticamente novo. Não havia esse cuidado, nem essa preocupação de... como é que se diz?, de perfeição. Mas havia boa vontade e essa boa vontade nos permitia dar sessões regulares, com filmes excelentes.

Marinho - Certo.

Selda - Como vocês conseguiam esses filmes?

Ivens - De aluguel... 
Marinho - ... da Cinemateca...

Ivens -E depois havia público pra essas sessões.

Marinho - Havia sessões que entravam umas quatrocentas e cinqüenta pessoas!

Narciso - Sim, mas que público era esse, essas quatrocentas e cinqüenta pessoas?

Marinho - Ou mais, ou, às vezes, mais...

Ivens e Marinho - Dependendo do tipo de filme.

Marinho - Por exemplo, McLaren lotava tudo.

Ivens - Filmes de Hitchcock, porque nós andamos exibindo filmes de Hitchcock.

Nós passávamos de tudo... Passamos o "Thin man”, do Anthony Mann, se lembra do Anthony Mann, não é? Se passava filmes de classe D...

Marinho - Ora, passava René Clair, pô!

Ivens - Passava René Clair. Se passou "Encouraçado Potemkin”...

Marinho - A sessão do "Encouraçado Potemkin" foi uma loucura, não é? Tinha gente saindo pelo ladrão...

Ivens - Passava Hitchcock, se passava filme de bang-bang...

Narciso - É. E teve aquele festival...

Ivens - 63,64.

Marinho-É, até mais ou menos aí... E teve uma sessão especial que foi o ciclo do cinema fantástico, onde houve uma série de debates a respeito, inclusive, de "A feitiçaria através dos tempos". Nós tivemos debates com o sociólogo André Araújo...

Narciso - Sim, o Marinho falou pela primeira vez na palavra debate, não é? Quer dizer, então, que havia debates normalmente?

Marinho - Ah, todas as sessões tinham debates. Terminando um filme, você abria a discussão...

Ivens - Tanto havia debates, como havia apresentações. De todos os filmes. Todos os filmes eram apresentados, tá?

Selda - Posso fazer um parêntese? Nós, no Cineclube Tarumã, tentamos isso, lembra? Apresentar o filme, ler a sinopse e depois vinha o debate... Outros cineclubes que andaram por aqui, depois de vocês, não se preocupavam muito com isso. Era só a projeção do filme e acabou-se.

Narciso - E o cineclube a que a Selda se refere também já é de público bem menor. Não há essa afluência que vocês falam com relação ao tempo de vocês, aí do GEC...

110 Somanlu, ano 7, n. especial 2007 
Cosme - Agora me refresquem a memória... eu me lembro que a gente fez uma sessão no cinema Éden.

Ivens - No Éden, não.

Marinho - "A face oculta".

Cosme - Aquele cinema era o Éden.

Marinho - Era o Éden, sim...

Selda - Que foi o Veneza...

Ivens - Ali não foi. Eu vou explicar...

Cosme - Eu me lembro que eu estava na cabine com o projetor 16. Tinha gente! E era um filme brasileiro.

Ivens - Não. Eu vou explicar. Deixa eu explicar como é que foi. No Éden, inclusive nós temos aquelas fotografias...

Marinho-De "A face oculta".

Ivens - Foi quando a Empresa Sul veio de São Paulo e alugou o Éden pra ser explorado por eles. Então, o Dr. Cajado fez um coquetel no dia da inauguração e passou "A face oculta" pra nós. O filme que você está querendo lembrar foi uma sessão que nós demos, porque já estávamos de conchavo com o Barata, no cinema Odeon, pra passar "O Saci” numa matinal. Você lembra? Houve uma sessão especial também que o Barata nos concedeu lá no cinema Odeon pra passar "O grande motim”, filme que era com o Marlon Brando...

Marinho-Marlon Brando!

Ivens - Uma sessão especial de lançamento do filme. Ele nos deu os ingressos, nós vendemos os ingressos, lembra disso?

Cosme - Mais ou menos. Eu me lembro do GEC, eu me lembro muito dessa sessão do GEC... estava entupida de gente...

Ivens - Agora você veja a força que o GEC tinha na mão. Havia responsabilidade e a turma acreditava na gente.

Marinho - Depois o GEC passou a ser um negócio de sócios. Não na fase inicial, mas depois, com a organização do GEC. Quer dizer, já depois do Cosme ter saído, quando o Ivens assumiu a presidência.

Ivens - Foi. Após o Cosme, eu passei pouco tempo, porque depois de mim...

Marinho - Aí veio o Guanabara.

Ivens - Não, depois de mim quem assumiu foi o Márcio.

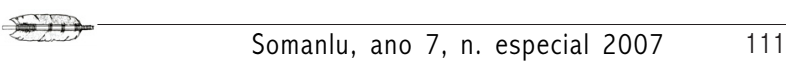


Marinho - Não, não. O Márcio foi depois do Guanabara. Depois de ti foi o Guanabara. Nós nos reuníamos na casa do Guanabara de Araújo, lembra disso? Ivens - É. Eu sei que eu saí de lá, a lembrança que eu tenho...

Cosme - O Guanabara tá na praça ainda?

Marinho - O Guanabara está vivo...

Paulo Graça - Quando começa a decair a experiência de...

Marinho - Não, espera aí, ouve mais uma parte da história. Aí começaram a surgir ciclos de cinema com uma série de estudos, em conjunto com o próprio Cosme. Porque aí o Cosme assumiu a Cinemateca do MAM - Museu de Arte Moderna do Rio de Janeiro e, então, como a Cinemateca organizava ciclos de empréstimo, de aluguel de filmes... aluguel, não, a pessoa tinha que pagar uma taxa irrisória na época, e começamos, então, a exibir uma série de ciclos lá no próprio auditório do Palácio Rodoviário, com a presença de todo esse pessoal. Mais ou menos em 1964, assumiu o Luiz Maximino no DEPRO - Departamento de Turismo. Então, nós conseguimos dinheiro e aí o negócio começou a criar raízes em termos de organização. Com esse dinheiro, deu pra começar a pagar esses ciclos envolvendo a Cinemateca canadense, a Cinemateca da Inglaterra...

Narciso - Da Tchecoslováquia...

Marinho - Dos Estados Unidos, da Tchecoslováquia, da Polônia, em conjunto quase sempre com a Cinemateca do MAM.

Cosme - Foi nessa época que você organizou o I Festival Norte de Cinema.

Selda - Antes disso, houve o Festival do Cinema Amador.

Narciso - Espera aí. Antes disso eu gostaria de lembrar o seguinte: o GEC foi para o Sesc/Senac. Eu já o conheci no Sesc/Senac.

Marinho - Não, não. Isso foi outra época. Isso foi a época da divisão. Houve um pessoal que se separou do GEC, aí houve a cisão. Começou a haver um movimento, mais ou menos uma movimentação política, chegaram a se fazer algumas sessões, quando foi, Ivens? Quando tu saíste...?

Ivens - Olha, quando o GEC saiu da minha casa, inclusive eu entreguei toda a documentação... O GEC tinha ata, toda reunião semanal, era tudo registrado em ata. No dia em que o GEC saiu da minha casa foi tudo entregue nas mãos deles. Eu praticamente me afastei, porque aí ... eu já era casado desde 1960, mas em 64, quer dizer, minhas filhas tavam começando a crescer e eu precisava cuidar da minha vida, porque o GEC me tomava, além do tempo, dinheiro. E a turma nova que tava

112 Somanlu, ano 7, n. especial 2007 
Cosme Alves Netto

chegando era uma turma que não pensava da maneira como eu e o Cosme pensávamos. Então... era cabeça de Joaquim Marinho, era cabeça de Márcio Souza, compreendeu? Eles já olhavam o GEC não como um meio de diversão, cinemadiversão, e sim o GEC como cinema atrativo, um chamariz político, entendeu? Então, já não havia mais aquela preocupação de se analisar, de se olhar o cinema por todos os ângulos. Havia um direcionamento. Então...

\section{"Eu disse que Max Linder era melhor que Chaplin e quase levei porrada, rapaz"}

Paulo - E o público nessa época?

Ivens - Ah, o público já era totalmente politizado. Então, só era estudantada, né?

Paulo - Sim, mas era menos, mais?

Ivens - Eles conseguiram bom público inicialmente, porque o Márcio freqüentava o Colégio Dom Bosco e criou um cineclube lá dentro; e tinha o GEC do lado de fora, compreendeu? Nessa fase eu já estava afastado. O que eu posso dizer para vocês é o seguinte: que eles fizeram um festival em homenagem ao Chaplin e me chamaram. E o Márcio sempre foi um cara muito honesto comigo e eu sempre fui honesto com todos eles. E o Márcio chegou comigo e disse: "Ivens, eu estou com um grande problema dentro do GEC". "O que é?". "Não há maneira, não há possibilidade de fazer um debate, porque ninguém fala. Então, eu quero que tu vás lá nesta noite para esquentar o chá". "Tá bom, eu vou". E a polêmica começou desde a hora de eu escrever a apresentação, porque tudo era em homenagem ao Chaplin, porque todo mundo ia por ser só o Chaplin. É uma curiosidade, né? Eu botei assim: "Chaplin, um grande artista se não existisse Max Linder, mas Max Linder ..." ou um negócio assim, eu citava Max Linder dizendo que era mais que o Chaplin. Rapaz, aquilo antes da sessão começar já foi um pau pra quebrar!”

Marinho - Tem mais um detalhe histórico nessa sessão, porque foi a primeira vez que se colocou em exibição filmes do Chaplin, que eu havia conseguido com uma pessoa aqui de Manaus, o seu Joaquim Santos. Eram filmes do Chaplin, de bitola 9 e meio milímetros.

Ivens - Eram meus.

Marinho - Não, aqueles eram do velho Joaquim Santos, que depois até eu te dei.

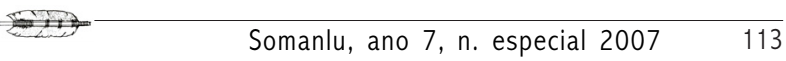


Ivens-É, é.

Marinho - Tu tinhas a máquina e ele os filmes do Chaplin em nove e meio. Tu não tinhas os filmes.

Ivens - É, é.

Marinho - Aí é que ele pegou e doou os filmes pra gente e eu te dei os filmes. E era a primeira vez que se passava filmes em 9 e meio, ou seja, os furinhos da fita eram no meio do quadro e não nas laterais como agora. Foi a primeira vez que publicamente se exibiu isso, porque o Ivens tinha a máquina...

Cosme - No meio do quadro, não, era no quadro todo.

Selda - Era a "Pathé-Baby"?

Ivens - Sim, uma "Pathé-scope" ...

Marinho - Então, nessa sessão, que já foi depois que o GEC se mudou para o SESC, porque aí houve um problema de ordem técnica no Palácio Rodoviário. O Randolpho saiu, por motivos políticos, o Randolpho foi afastado depois de 64 ...

Ivens - Aí já eram vocês, eu tava mais afastado.

Marinho - O Randolpho foi afastado da função dele do Palácio Rodoviário e a gente se mudou pro SESC. Nós começamos a fazer as sessões no SESC. Foi quando surgiu esse primeiro festival e depois a sessão do Glauber Rocha, que o Glauber já estava filmando aqui ...

Selda - Mas isso é época do golpe ou é depois?

Marinho - Não. Isso foi depois do golpe...

Ivens - Depois do golpe. Já estava virando, já estava virando. Agora, a curiosidade... Selda - Mas tem uma história do golpe, não tem?

Marinho - Teve, espera aí que eu vou já te contar. Isso foi em $67 . .$.

Ivens - Em 64, nessa noite, eles tinham convidado o governador Arthur Reis. E aí, quando o pau tá quebrando lá dentro, rapaz, coincidiu de adentrar o governador com a senhora dele.

Marinho - Deixa ele explicar esse negócio pra Selda; é bom explicar pelo seguinte: o Márcio trabalhava ...

Ivens - O Arthur Reis disse: "Olha, eu cheguei atrasado, vi um pouco dos filmes aí, mas me interessei bastante. Eu quero saber quem foi que falou em Max Linder aqui dentro". Tinha sido eu. Ele disse: "Pois, olha, eu concordo com você". Quer dizer, foi uma ducha de água fria na cabeça de todo mundo, porque todo mundo tinha incensado o Chaplin, o Chaplin era isso, aquilo e aquilo outro. E todo mundo só

$114 \quad$ Somanlu, ano 7, n. especial 2007 
Cosme Alves Netto

tava faltando me dar porrada lá dentro, né? porque eu era um grosso, porque eu não entendia de porra nenhuma de cinema, esse caso todo. Então, foi isso. Quer dizer, é uma curiosidade... Depois, eu dizia pro Márcio: "Porra, Márcio, vão acabar me dando porrada, vão me jogar da janela lá embaixo. Eu vim aqui pra tocar fogo no pessoal..." Aí o Márcio se apavorou, né?, porque foi um "pára pra acertar", ainda mais com o governador lá dentro. E era o governador da Revolução, né?

Narciso-É... Nessa época ...

Marinho - Peraí... Toda essa estória do Arthur Reis e a movimentação do GEC no Sesc; é que o Márcio era assessor do Arthur Reis na questão da reedição de livros, naquela fase inicial do Arthur Reis, das edições do Estado. O Márcio é quem fazia a seleção, preparava as orelhas, aquele negócio todo, e conseguiu com o velho Arthur que, pela primeira vez, nós levássemos uma comitiva oficial para o Festival de Cinema de Salvador, ou melhor, as Jornadas de Cineclubes em Salvador, onde estava o Glauber, o Walter da Silveira, aquele pessoal todo. A gente voltou a se encontrar com o Cosme, aí se convidou o Glauber para vir a Manaus. Houve apoio do governador naquela época, em pleno 64/65...

Cosme - Você não me encontrou em Salvador porque naquela época eu já estava em cana.

Marinho-Ah, estavas preso!

Cosme - Inclusive, saiu desse Encontro um abaixo-assinado...

Marinho - Sim, tens razão.

Cosme - ... que o Ivens não quis assinar... (risadas)

Ivens - Não, peraí! Eu nem fui! Dois detalhes: quando estourou 64, eu estava no Rio de Janeiro e nessa confusão lá no Rio eu quis falar com o Cosme. Chegou um cara comigo e disse assim: "Olha, não fala no nome do Cosme porque ele está em cana, tá lá em cima, no ...”, como é?

Marinho-Cenimar!

Ivens - Não, no...

Cosme - No Alto da Boa Vista.

Ivens - "No Alto da Boa Vista, e você não é daqui, cuidado, senão vai acabar entrando em cana, e vai ser duro à bessa". "Mas, eu não tenho nada que ver, não sou político, pô, Cosme é meu amigo, eu conheço Cosme da minha terra, ele é amazonense como eu" - "Cala a boca, fica caladinho aí, mas não se preocupa, não, que ele vai saber, tudo bem, tudo jóia, pode sossegar.” - “Tá bom”. Foi a primeira saída. Esse 
negócio que o "seu’ Joaquim tá falando aí, de lá de Salvador, da Bahia, quem entrou pelo cano fui eu, colega. Pois, quando foi pra ir para Salvador, o "seu" Márcio Souza foi me pedir, me buscar na repartição, para que eu fosse, engrossando a comitiva, falar junto ao Governador para cavar umas passagens para ir lá para Salvador. "Mas eu não posso!". "Não, vamos lá, cara”. Chegamos lá, me botaram na frente, fizeram eu falar. Eu falei. Aí o homem disse: "Ah, tá bom, não tem problema nenhum, vocês vão viajar". Aí, eu pensei: "Rapaz, vou para Salvador!". Qual é a minha surpresa quando depois eu soube que foi Márcio Souza, Joaquim Marinho, não sei quem foi o outro. Eu sobrei...(risadas). Bom, tá registrado aí para a História: banquei o inocente e útil. (risadas).

Narciso - Mas, aí o Glauber vem a Manaus...

Ivens - Aí o Glauber vem a Manaus...

Narciso - Foi aí que teve aquela famosa sessão no GEC.

Marinho - Peraí, tem outra coisa intermediária ... Bom, nesse meio tempo já estava ocorrendo o Departamento de Turismo com o Maximino. Então, surgiu a idéia de se fazer um filme a respeito do Amazonas. Tínhamos ligações com Paulo Gil Soares, que estava naquela época vindo até aqui, e aí se contrata o Glauber. Foi quando ele veio aqui, e houve uma sessão famosíssima, onde ele fez um debate, acho que tu estavas nesse debate, não, Ivens?

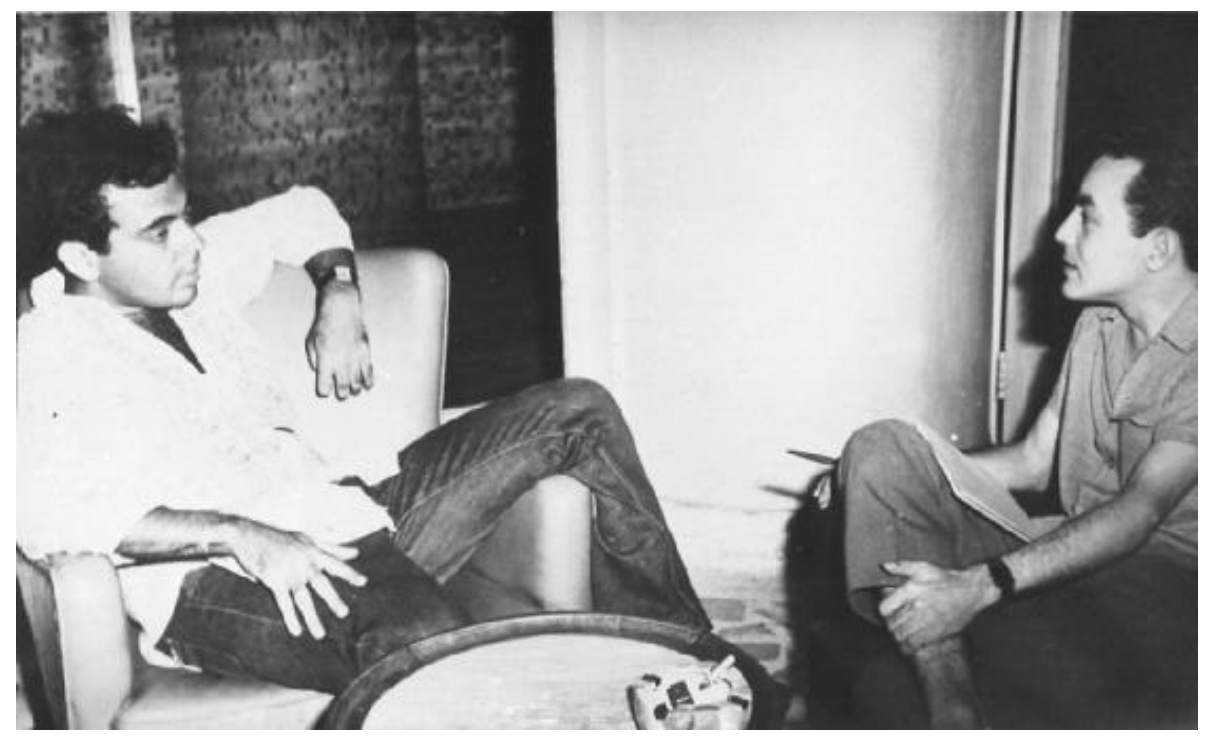

José Gaspar entrevista Glauber Rocha para "A Crítica”, em 20 de dezembro de 1965
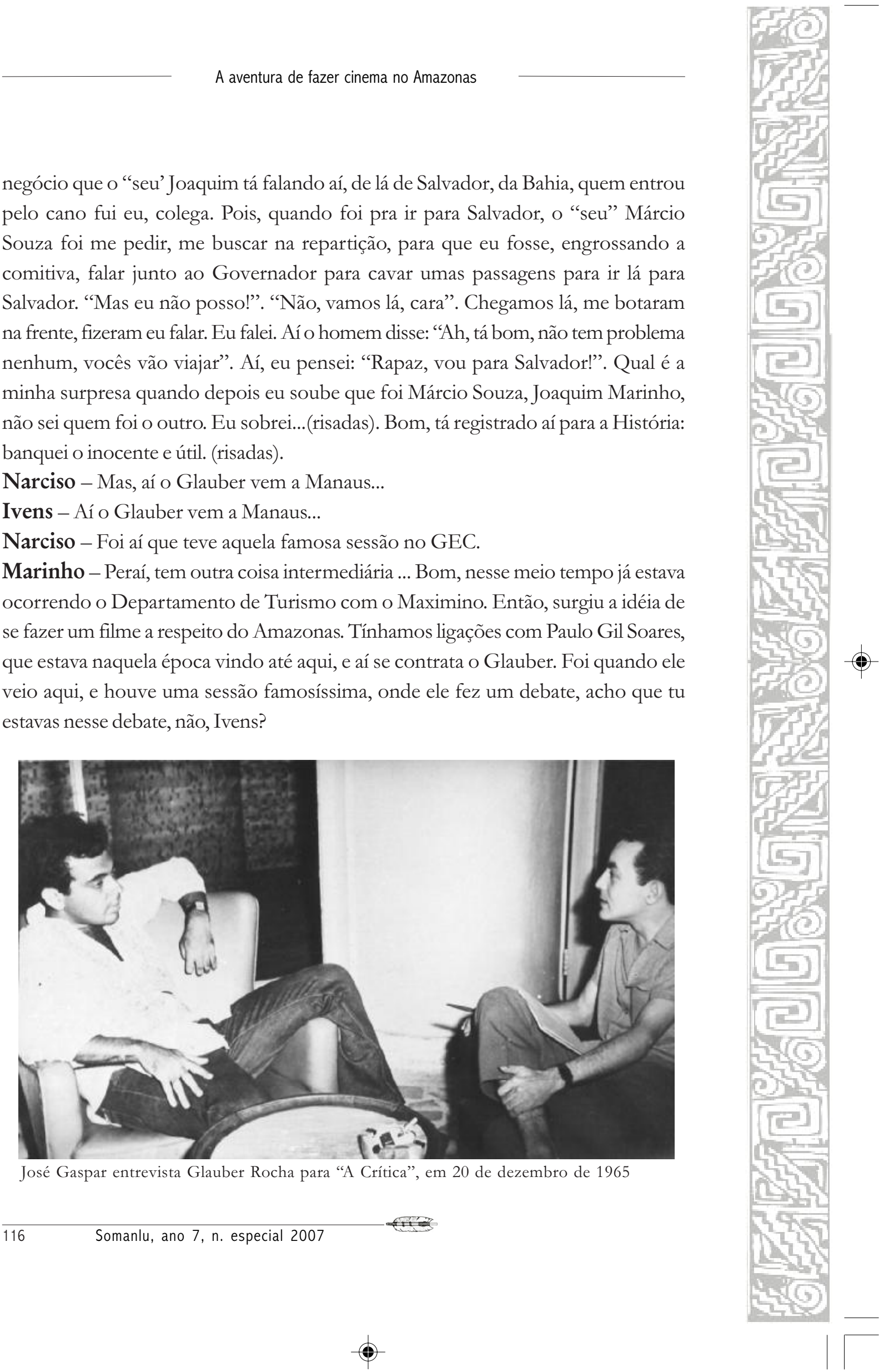

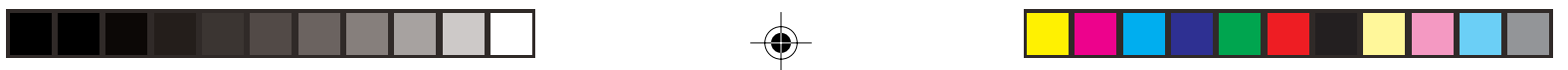

Cosme Alves Netto

Ivens - Não, eu me encontrei depois com ele, lá no Hotel Amazonas, e houve uma conversa entre eu e ele a respeito de cinema no Amazonas, e essa conversa foi registrada através de uma fotografia, que eu guardo até hoje comigo.

Cosme - Pô, tem que pegar essa fotografia...

Marinho - Bom, ele fez o papo lá sobre cinema, realizou o filme "Amazonas, Amazonas" que passou aqui mais de dois meses. E logo depois disso, mais ou menos em 67, foi quando surgiu o problema com "L'Age d'Or". Foi em 67, não é?

\section{"Tivemos que explicar o significado do filme "L'Age d'Or", do Buñuel, para os policiais de Manaus"}

Cosme - Por aí... a censura apreendeu...

Marinho - Bom, o Cosme estava na seleção dos filmes e mandou "L'Age d'Or" para ser exibido em Manaus, que era um ciclo Buñuel. Passa-se "L'Age d'Or", a Polícia Federal...
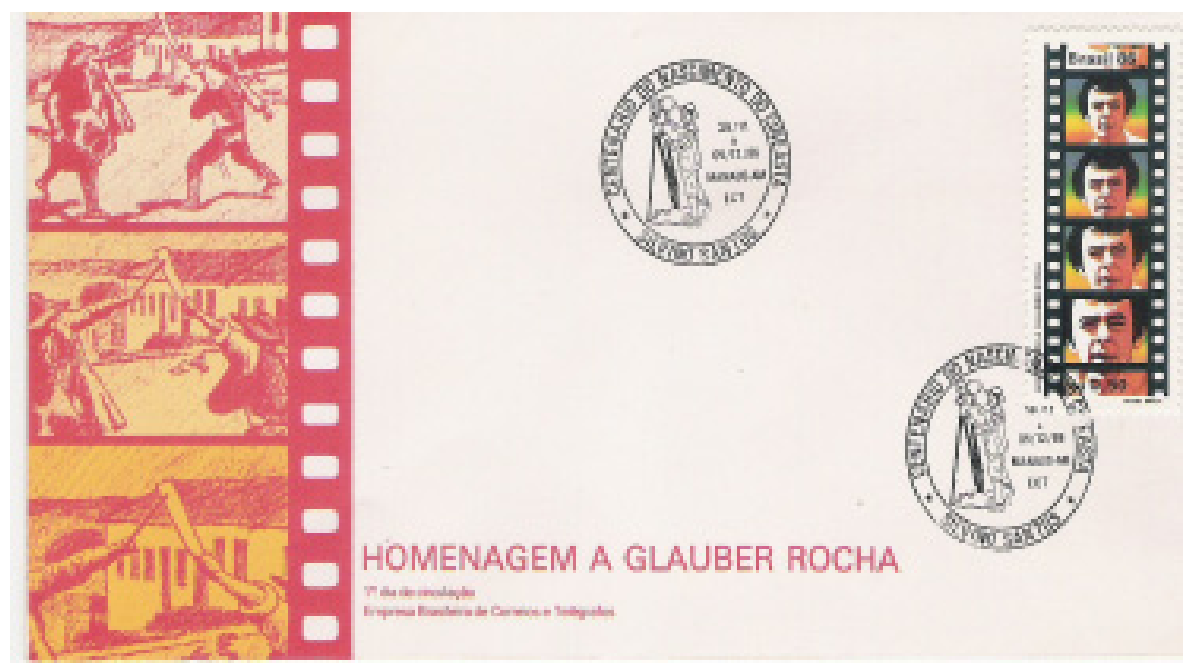

Carimbo comemorativo dos Correios ao centenário de nascimento de Silvino Santos e selo postal de Glauber Rocha, 1986 (Acervo Selda Vale).

Ivens - Mas é preciso se dizer onde era. Era no Auditório lá em cima da Biblioteca Pública.

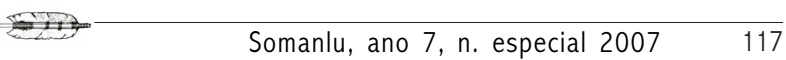


Marinho -É, aí já se estava no Auditório “Alberto Rangel”. Foi o tempo em que o Arthur Reis inaugurou o Alberto Rangel, e o Alberto Rangel foi quase que especificamente feito para conferências e para o Cineclube funcionar, porque estava empolgado com a realização dos trabalhos com o Cineclube. Então, passou tudo para o Alberto Rangel. Começaram a voltar as boas sessões, porque o Sesc não tinha condições. Foi quando houve a separação. O Roberto Kahané e o Lindoso saíram do GEC. É, o Felipe Lindoso. Criaram uma dissidência do GEC e voltaram ao SESC para fazer sessões lá, com filmes completamente diferentes. E a gente continuou com a parte histórica no GEC. Foi quando se exibiu "L'Age d'Or" e o Coronel Canini, que era o cara do SNI, resolve apreender o filme. Bom, apreendeu o filme, tentou segurar o filme. Naquela época, eu trabalhava na Manaos Harbur, r. eu tinha carro cedido pela Manaos Harbour, a gente conseguiu pegar o filme e levar para a Ponta Negra...

Cosme - Levar para onde?

Marinho - Para a Ponta Negra [praia]. O cara andou atrás do filme, mas não conseguiu localizá-lo. Nós, no dia seguinte, de manhã, fomos com o Arthur Reis. Aí o velho Arthur Reis (isso é para mostrar a diferença, engraçadíssima, em termos inclusive de política aqui no Estado do Amazonas. Por exemplo, em plena época da repressão, um cara, como o Arthur Reis, que tinha sido colocado por toda aquela repressão política, era um sujeito que dava a maior abertura em todos os setores da atividade cultural). Ele pega ...

Paulo Graça - Mas, é porque o populismo anterior tinha sido mais violento que a própria ditadura de 64.

Marinho - Sim, mas é para mostrar a grande diferença do pós - 64 no Amazonas, e do que tinha sido o populismo. Aí se deu o seguinte: Ele dava a maior cobertura para a atividade cultural, construindo um auditório como o Alberto Rangel, hoje destruído, fazendo, por exemplo, edições de obras de quase todos os autores amazonenses, levantando quase toda a memória histórica do Amazonas, em termos de literatura, dando cobertura a festivais de cinema e tudo mais, e, de uma hora para a outra, enfrentando, inclusive, e exigindo do general Ademar Queiroz, que era o comandante militar da região, a demissão desse coronel Canini e "engrossando" com ele por causa de um simples filme. A Igreja e a Polícia Federal não tinham gostado do filme. Fizeram comentários com o Arcebispo, com o comandante de polícia, com o comandante de não sei que mais ... Arthur Reis "peitou" esse coronel

118 Somanlu, ano 7, n. especial 2007 
Cosme Alves Netto

Canini para que ele, de maneira alguma, perseguisse mais ninguém, tanto que, logo no dia seguinte, eu já estava como diretor de Turismo do DEPRO. Eu viajava e nos jornais saía que eu tinha sido preso e levado para o Rio de Janeiro em função do filme não ter aparecido e ter sido apreendido. Esse negócio criou uma história nacional, saiu até no New York Times. A partir daí a gente começou a exibir uma série de filmes mais comerciais, que tinham mais facilidade de poder chegar até aqui, devido a esses problemas políticos. Houve um inquérito, que até hoje é guardado, e todos nós fomos depor na Polícia Federal. Foi quando houve a abertura do inquérito na Polícia Federal, para se dizer por que tínhamos passado o filme, o que é que nós achávamos, quais eram os significados das cenas... A mais engraçada foi essa pergunta: "Por que a vaca era jogada pela janela, ou estava na cama? Por que o corte do olho com a navalha?" Tínhamos que interpretar o pobre do Buñuel...

Narciso - Mas, tinham que perguntar é do Buñuel e não de vocês...

Marinho - Eu sei, mas o inquérito era policial e foi aberto um IPM, inquérito policial militar. Tu não chegastes a ser chamado nesta, não? (para o Cosme).

Cosme - Não, só queria registrar para a história que o Arthur Reis é meu primo (risadas).

Narciso - Eu queria colocar uma outra coisa. Em 54 , aparece a crítica cinematográfica com o Ivens Lima, depois veio o GEC e tudo isso. Em 67, o $1^{\circ}$ Festival de Cinema Amador do Amazonas...

Marinho - Sim, Mostra de Cinema Amazonense, foi isso, não? Não. O Clube da Madrugada foi quem fez o $1^{\circ}$ Festival de Cinema Amador.

Narciso - Apareceram filmes como "Carniça" e "Harmonia dos contrastes".

Marinho - E teve o filme do Hanneman, também.

Narciso - "Um pintor amazonense". Era um super 8.

Marinho - Sim, mas também fazia parte do Festival. Hoje mesmo peguei, por acaso, o programa de uma Mostra de Cinema Amazonense, que foi realizada lá no Alberto Rangel, com o desenho de capa do Hanneman Bacellar, onde foi mostrado o filme do Ivens sobre as mãos, era baseado num trabalho que ele fez com o Cesídio Barbosa.

Narciso - Mas, como é que foi esse Festival, o que representou?

Marinho - Ah, isso o Ivens pode dizer melhor, pois foi organizado inclusive com a participação dele.

Ivens - O negócio é o seguinte: esse $1^{\circ}$ Festival de Cinema Amador do Amazonas

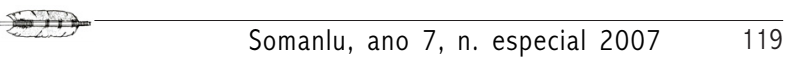


foi patrocinado por uma firma do Rio de Janeiro, chamada J. Borges Filmes. E foi O...

Marinho - Mas é interessante tu contares a estória do J. Borges também...

Ivens - Era um cidadão que foi contratado pelos serviços de propaganda do governo Arthur Reis para divulgar, para difundir as coisas amazônicas, não só aqui na cidade como também em todo o Brasil. Então, ele tinha uma cadeia de cinemas e ele distribuía um cinejornal, era um tipo de documentário que ele fazia e que distribuía no Brasil inteiro. Borges pretendia agradecer o que ele estava recebendo do governo aqui (mensalmente ele vinha a Manaus fazer um documentário) e criou esse prêmio em Manaus para estimular o cinema. E descobriu o Cesídio Barbosa, que vale a pena a gente registrar como grande cinegrafista, e o Albertino, que era um auxiliar cem por cento, um cara dedicado também às coisas de cinema. E como os dois não eram ligados à imprensa, eles se lembraram de mim e me chamaram. E o Borges me chamou e disse: "Olha, eu quero fazer um Festival, assim, assim, você, como é que pode fazer?". Eu: "Olha, eu tenho interesse, inclusive de participar". Ele: "Você toma conta do Festival e você participa". Tudo caiu em cima dos meus ombros. Então, nós partimos para a luta.

\section{"Nós filmávamos de tarde e à noite revelávamos o filme no quintal lá de casa. Eu e o Cesídio Barbosa”}

Aqui entra a história da vaidade humana; no início, ele disse a mim: "Eu não quero aparecer, quero dar esse prêmio, mas não quero aparecer”, porque não acreditou no meu trabalho, isso é que é certo. Então, o que é que eu fiz? Procurei o Aluízio, que era o presidente do Clube da Madrugada e meu amigo até hoje, o Aluízio Sampaio, e como eu já fazia parte do Clube da Madrugada, eu propus a idéia a ele. "Ora, nós endossamos, não tem problema nenhum, o Clube da Madrugada endossa e vai te apoiar". Procurei a Rádio Rio Mar, o Erasmo Linhares, e o Erasmo também ... (eu ainda trabalhava na Rio Mar naquele tempo): "nós vamos endossar, não tem problema nenhum". Tinha o cinema Avenida na minha mão, da empresa Bernardino. Falei com ele, ele disse: "Pois não, no dia em que você quiser, nós vamos te ceder o cinema à noite pra você fazer a sua sessão". Aí, eu lancei o Festival, as bases do Festival, abri a inscrição, e continuei a trabalhar em cima do meu filme. Resultado, o "Carniça" vence... tem uma outra história para ser contada... Era o filme do Litaif.

120 Somanlu, ano 7, n. especial 2007 
"Harmonia dos Contrastes", que foi o meu filme, eu digo meu, porque eu era o produtor, e fui ator, diretor, o Cesídio foi o câmera. Vale aqui registrar que 90\% desse meu filme foi revelado no quintal da casa do Cesídio. Nós filmávamos de tarde e à noite, às 10 horas da noite, nós víamos o negativo. Fizemos o filme todo em negativo, sabe disso, não? (para o Marinho). Todos os negativos revelados aqui mesmo em Manaus. A copiagem e a contratipagem nós mandamos para São Paulo. E houve outros concorrentes. Por exemplo, o Kahané concorreu com um filme super 8 sonoro. Bem, no dia do Festival foi designada uma comissão e o "seu" J. Borges já não estava mais gostando do meu trabalho, porque J. Borges Filmes era uma firma, uma empresa que apenas participava dando prêmios, quer dizer, ele no início não queria nada, depois achou que a firma tinha ficado em segundo plano. Aí eu disse: "Rapaz, você disse uma coisa..."; "Não, você foi quem entendeu mal!"... porque o Festival estava praticamente para terminar, tá compreendendo? Não tinha mais nada para ser feito...

Narciso - Emplacou, né?

Ivens - É, emplacou. Então, o que é que ele faz? Manda vir um cara do Rio de Janeiro para ser presidente da comissão. Esse cara chegou aqui fora de hora. Reuniu aí, se não me falha a memória, o padre Ruas, o Gaspar e mais não sei quem, para ser a Comissão Julgadora. Eu, que tinha organizado o Festival, não soube quem era a comissão julgadora!

Cosme - Quem era esse cara?

Ivens - Era um picareta, não sei nem como é o nome desse cara. Era um ilustre desconhecido. Era um "Salieri”, um desses 'Salieri”" da vida...

Marinho (rindo) - Bem colocado!

Ivens - Pois bem! Então, sabe o que é que diziam pra mim no dia do Festival? Que eu teria ganho, que quem iria ganhar o festival era eu... O Festival era 500 mil cruzeiros, 300 mil e 200 mil. Eu ganhei o $3^{\circ}$ lugar! Porque, às 4 horas da tarde, fizeram a exibição dos filmes sem que eu soubesse! E à noite, chegaram lá e disseram: “O filme que tirou o $1^{\circ}$ lugar é o 'Carniça'?'.

Narciso - É, como todo festival tem seus escândalos, Manaus não seria a exceção. Ivens - Agora, outra coisa: o meu filme foi projetado na íntegra, certo? O "Carniça” também. O do Kahané, que tirou o $2^{\circ}$ lugar, não chegou a ser projetado. Na metade, a máquina pifou e não foi exibido. Posteriormente, esses filmes foram projetados pelo Clube da Madrugada no "Café do Pina". Numa noite, o Aluízio disse: "Vou

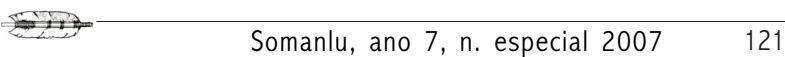


projetar aqui do lado do Quartel da Polícia, para todo mundo ver aqui na praça”. O meu filme foi projetado, o Kahané não permitiu que o dele fosse e o "Carniça" também. Bom, são essas coisas...

Narciso - Por essa época houve uma produção de cinema no Amazonas que não se sustentou e caiu, né?

Marinho - Peraí, vou prosseguir. Depois, se fez uma apresentação do "Amazonas, Amazonas", também em avant-première, no Avenida, que foi alugado do Adriano Bernardino e depois se fez o $1^{\circ}$ Festival Norte do Cinema Brasileiro.

Narciso - É, 69.

Marinho - 69. E era idéia já de se tentar fazer bianualmente. A idéia inicial era essa, um festival de cinema, para congregar forças que levassem ao surgimento de um pólo de cinema na região amazônica. Isso tinha sido conversado na Bahia, e trazer para Manaus, que não vinham nunca, os filmes novos. E se conseguiu isso numa organização conjunta. O Márcio estava preso em São Paulo e o Cosme estava preso no Rio. Então, se movimentou isso com o pessoal que ajudava o Cosme na Cinemateca do MAM e com os que ajudavam o Márcio na Cinemateca Brasileira, em São Paulo, e se conseguiu uma série de filmes, totalmente inéditos, inclusive no Brasil. "Macunaíma", a primeira exibição de "Macunaíma", depois da Censura, foi em Manaus, ainda com a Censura metendo a mão nos buraquinhos de exibição da parede para tapar a bunda de Dina Sfat. E o filme não estava nem cortado, não se permitiu que se cortasse, e tivemos, ainda naquela época, o beneplácito da Censura e o cara disse então: "tudo bem", e meteu o dedo. E há uma cena famosíssima de tudo isso. É a cena em que a Dina Sfat está na rede, nua, com a bunda para cima e o cara da Censura meteu o dedo na frente. Só que ele tinha um dedão imenso, e na hora em que ele mete o dedo na frente do projetor apareceu na tela o dedão dele como se fosse um enorme cacete. Então, levou uma vaia geral... foi uma apoteose! Isso no Cine Odeon (risadas). Passou-se, como filmes inéditos: "A mulher de todos", do Rogério Sganzerla, que esteve presente com a mulher dele, a Helena Ignez; projetou-se "Brasil ano 2000", do Walter Lima Jr., também inédito, que tinha saído da Censura para ser exibido em Manaus, e foi exibido sem qualquer corte, e do Joaquim Pedro, o "Macunaíma". Ele também veio para Manaus, foi o vencedor do Festival. O filme dele também era inédito, não tinha sido exibido no Brasil; e teve outros, lembra? Teve aquele do vampiro...

Cosme - Do Iberê?

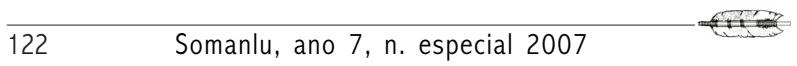


Marinho - Do Iberê Cavalcante, "Dança dos vampiros"... Não, não é..., é "Sonho de Vampiro!".

Ivens - Tinha esse e aquele do anjo... o "Copacabana me engana".

Marinho - "Copacabana me engana”, exatamente.

Ivens - Quem é o anjo, aquele velhão... como é, aquele gordão que fazia...

Marinho - Jô, Jôfre Soares!... Não era o Jôfre Soares?!

Ivens - Como é??... Fregolente!

Marinho - Fregolente. E teve o filme do Tarcísio Meira, que é aquele policial, vagabundérrimo..., do Tarcísio Meira. Então, foram sete filmes exibidos. Desses, quatro eram totalmente inéditos e três já tinham sido exibidos no Rio ou em São Paulo. Foi aí que se descobriu o Silvino Santos. Aí o Cosme pode entrar porque foi o pai dele quem fez a indicação, lembrando do Silvino Santos...

Cosme - Aí eu acho interessante a gente resumir um pouco para entrar num problema da memória do cinema brasileiro e da formação desse pessoal que mais tarde passou a fazer cinema.

Ivens - Cosme, só uma observação, rapidamente. Vou registrar um nome aqui. A crônica falada já foi comentada, não é? Eu fiz crônica falada, comentário falado; o Zé Gaspar fez através da Rádio Baré, mas, escrita, houve um rapaz chamado Fernando Dinelly, com outro pseudônimo, Paulo Laranja, que era o contrário de Pedro Lima, né, que era do Rio. Fernando Dinelly da Costa foi um dos que sofreram, inclusive, pressão dos proprietários de cinema e foi proibido de escrever em jornal por causa dos proprietários de cinema...

Paulo - E o Márcio, não fez?

Ivens - O Márcio fez também.

Marinho - Fez o Márcio, fiz eu, o Ivens depois.

Cosme - Eu cheguei a fazer também...

Marinho - O Cosme fez também.

Cosme - ... com o pseudônimo de Ariel, mas a mesma pressão também se fazia no "Jornal do Comércio", que era do Baraúna, que era muito amigo do meu pai, chegou um dia e disse: "Olha, o problema é o seguinte, se você continuar escrevendo, eles tiram a publicidade do meu jornal".

Marinho - Isso foi o que aconteceu com todo mundo. Por exemplo, meu pai, que era advogado do Bernardino, fez pressão para que eu deixasse de escrever. Naquela época, eu escrevia no "Diário da Tarde"; era uma página inteira, com fotografias, 
que saía às segundas-feiras. Nós montávamos a página, eu e o Márcio montávamos domingo à noite e ela saía às segundas-feiras, uma página inteira. Era realmente uma loucura, porque havia pressão, porque a gente comentava o filme, e dava nossas opiniões assinadas. Então, no dia seguinte, o filme que estava passando no Avenida, no Odeon nem tanto, porque a pressão era menor, mas no Avenida era muito mais barra pesada, por parte do Aurélio, por parte do Bernardino, era um negócio... [Entra Nuno, com sorvetes para todos e o anúncio do novo Ziz-Cascalhão!] Narciso - O Cosme está querendo introduzir a questão da memória histórica... Marinho - Deixa só eu dar uma terminadazinha nessa parte.

Selda - Arre, não termina nunca!

Marinho - Tá uma zorra!

Cosme - Vai lá, vai lá!

Marinho - Nessa parte, por exemplo, de rádio e jornal na época, foi uma coisa que criou um certo estilo. Por exemplo, o Ivens teve problemas de ser proibido de entrar em cinemas, eu também, o Márcio também e nossos próprios jornais, porque o Márcio fazia na "Gazeta”, eu fazia no "Diário da Tarde" e o Ivens na Rádio Rio Mar. Depois, tu acabastes o programa, não foi? (Para o Ivens). Eu comecei a fazer o programa na Rádio Baré. Aí eu fiz o programa "Chegou a Hora do Cinema”, na Rádio Baré... Era também nos domingos e com mais alguma facilidade. O Ivens era representante da Chantecler e eu era representante da Phillips, tinha mais facilidade de chegar aos discos originais das trilhas sonoras. A gente fazia já com um pouco mais de requinte. Era dificílimo chegar uma trilha sonora a Manaus como chega hoje em dia. Então, para se conseguir um disco de trilha sonora era um milagre. À parte essa movimentação toda, o Festival de Cinema deu uma outra conotação, não só política mas também comercial do cinema no Amazonas. Mas aí, surgiu a Zona Franca. A partir daí...

Narciso - Eu acho que 69, o I Festival Norte de Cinema foi o marco final.

Marinho - Exato.

Narciso - Apesar do surgimento e do aparecimento de Silvino Santos, que abriu, vamos dizer, uma perspectiva...

Cosme - ... que ninguém tinha pensado antes.

Narciso - ... que ninguém tinha pensado. Se tinha uma mina...

Marinho - Tinha-se uma história.

Narciso - Sem saber, nós tínhamos uma mina no Amazonas.

124 Somanlu, ano 7, n. especial 2007 

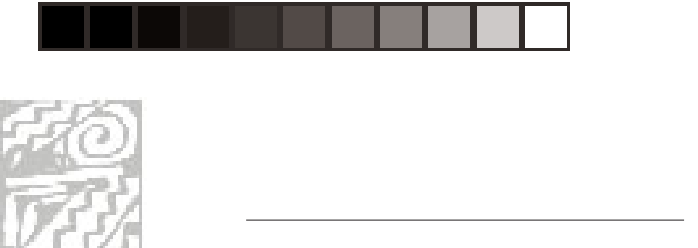

Cosme Alves Netto

Ivens - $\mathrm{O}$ último lampejo ainda da luta pelo cinema, modéstia à parte, quem fez fui eu, quando foi criado o Cinema de Arte, que eram umas sessões especiais que eu fazia às 11 horas da noite de sábado no Cinema Avenida. Vale a pena registrar, porque eu consegui fazer perto de 60 ou 70 apresentações. E um belo dia eu fui chamado pela Censura e recebi ordem de acabar com o Cinema de Arte. Eu dialoguei: "Mas, rapaz, não há problema nenhum. Os filmes são censurados, tá aqui o certificado de Censura". Ele disse: "Olha, ou você pára ou então você vai em cana”. E entre uma coisa e outra, e ser fechado o cinema, que o próprio dono do Cinema também foi ameaçado, eles me chamaram e disseram "olha, vamos parar..."

Narciso - Era a Dona Yayá e o "seu”...

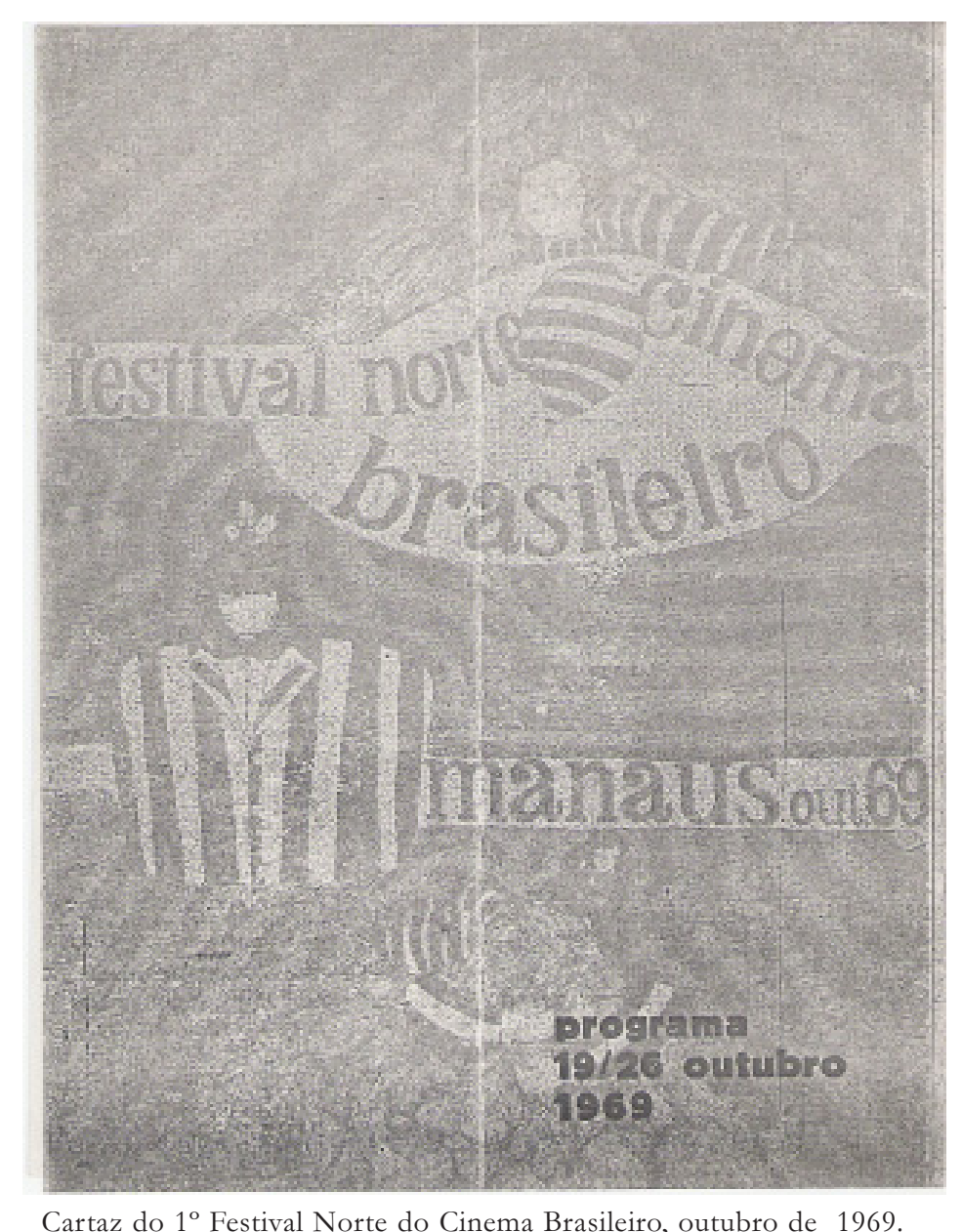

Cartaz do $1^{\circ}$ Festival Norte do Cinema Brasileiro, outubro de 1969. 
Ivens - Não, esses dois nem participavam. Foi o próprio Adriano quem me chamou e me disse: "Olha, tou nessa situação...". Agora, o troço mais absurdo é que para poder funcionar e usar o nome de Cinema de Arte, eu tive de me associar ao Rio de Janeiro, pela Associação dos Cinemas de Arte, não foi, Cosme?

Cosme-Foi.

Ivens - E quando houve esse problema, eu entrei em contato com eles no Rio de Janeiro e o Fabiano Canossa começou a se movimentar por Brasília, por ali, por acolá e tal, mas acabou "morrendo em Neves" também. Foi o último lampejo! Eram só filmes escolhidos, havia realmente uma grande receptividade, os filmes eram apresentados da cabine, eu fazia apresentação de todos os filmes antes de começar a sessão, na penumbra, comentários de cinco minutos, para passar a fita, e eu sei que eu fui vigiado, quer dizer, em toda a sessão havia agentes lá. Nós levamos "Os Companheiros", o filme do Monicelli.

Marinho - "Os Companheiros" foi uma loucura!

Ivens - Nós passamos três vezes em seguida, e toda a vez que o Sindicato queria reunir gente, assim, botava "Os Companheiros" e ...

Narciso - Até hoje! Até hoje!

Marinho - O problema surgiu, Ivens, por causa de "Os Companheiros". Foi quando houve proibição nacional de "Os Companheiros" e que tava exibindo aqui.

Narciso - Mas, vamos retornar ao Silvino Santos!

Cosme - Acho que o Festival de Cinema aqui foi um divisor de águas, porque aí você tem duas vertentes que são aparentemente duas vertentes bem afastadas uma da outra, mas que de qualquer maneira se completam. Você tem, a partir de toda essa experiência de GEC, de formação de público que culminou com o Festival de Cinema, o surgimento das pessoas que vão se dedicar à realização cinematográfica. Então, você tem Roberto Kahané, você tem Domingos Demasi, que podem...

Marinho - Felipe Lindoso, Djalma Batista...

Cosme - ... Djalma Batista, Felipe Lindoso, que vão se dedicar em diferentes graus à realização cinematográfica. E alguns hoje em dia são cineastas reputadíssimos. Djalma Batista é um cineasta consagrado, já tem vários longas-metragens na bagagem; o Roberto Kahané parou de fazer cinema, mas...

Marinho - Estás te esquecendo de um nome...

Cosme - Quem?

Marinho - Antonio Calmon.

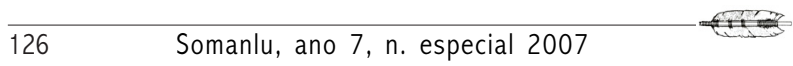



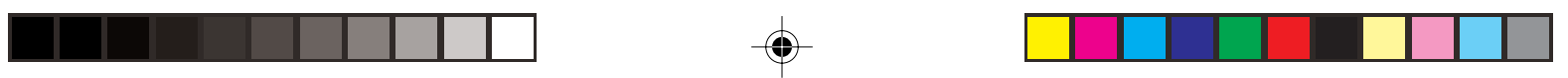

Cosme Alves Netto

Cosme - Antonio Calmon também é amazonense!... (várias vozes simultâneas).

Ivens - Antonio Calmon não participou...

Marinho-É, não participou, saiu daqui garoto. Mas é que tudo acontecia na Joaquim Nabuco. Tem que se levantar essa questão... É o “Ciclo Joaquim Nabuco”! Porque morava o Cosme na Joaquim Nabuco, eu, e o Calmonzinho, que morava logo depois do Grupo Escolar Barão do Rio Branco. O Calmon não tinha nada a ver com cinema, inclusive não freqüentava. Era só amigo de infância, de andar na rua, também com o Cosme. De qualquer maneira, também pegou a influência de viver, junto com a gente, a mesma época.

Cosme - Bom, mas de qualquer maneira, então, você tem pessoas que participaram desse período e que se dedicaram posteriormente ao cinema, tanto ao nível de realizadores quanto em outros níveis, como eu particularmente, que passei para a parte mais de pesquisa e de conservação, assim como o Ivens, e o Marinho, que se transformou em exibidor. Então, você tem de todo esse período a produção de algumas pessoas que realmente se integraram nas diversas faixas de cinema.

Ivens - $\mathrm{O}$ aprendizado foi o que resultou desse trabalho nos vários setores.

Cosme - Exato. O Festival de Cinema foi um outro marco muito interessante, porque aí surgiu o Silvino Santos. Aí já é outra vertente. Ninguém nunca tinha ouvido falar de Silvino Santos, talvez um ou outro soubesse, eventualmente. Eu, por exemplo, jamais!
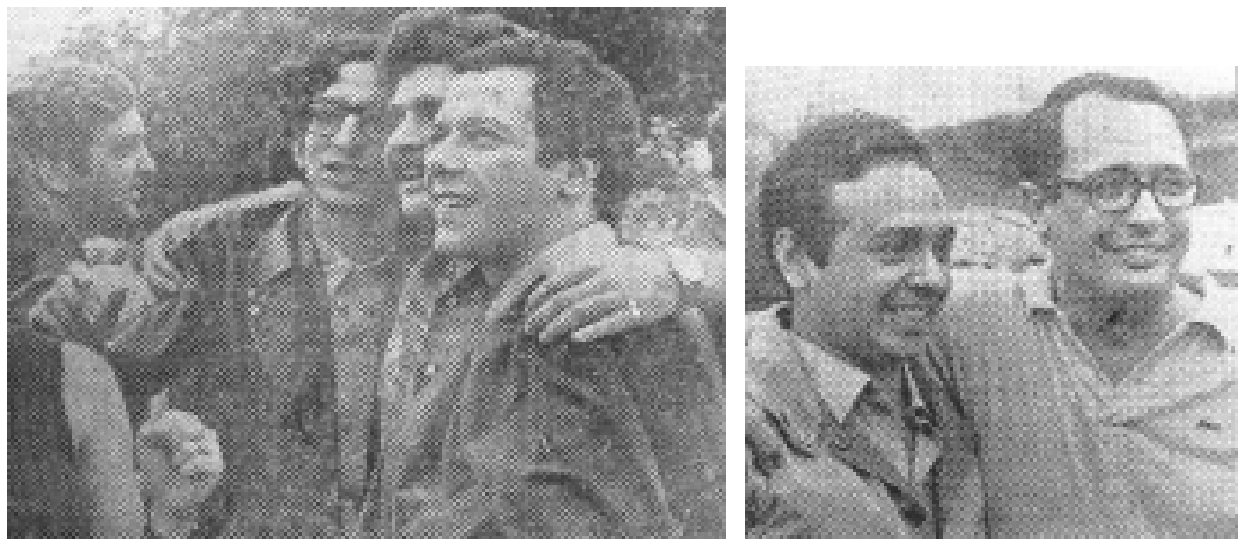

Aeroporto da Ponta Pelada: Domingos Demasi, Márcio Souza, Roberto Kahane e Fabiano Canossa. Cosme Alves Netto abraçado por Joaquim Marinho. ("Jornal do Commercio", 19 de outubro de 1969) 
Ivens - Eu, mas muito pouco...

Marinho-É, mas nós ligávamos Silvino Santos mais à fotografia.

Cosme - É, então, durante o Festival de Cinema, eu, na minha casa, nunca me esqueço disso, estávamos conversando no jardim de casa sobre cinema e tal, na Joaquim Nabuco, aí apareceu meu pai na janela e...

Marinho - Mas isso foi antes do Festival, foi na primeira reunião preparatória do Festival, foi logo que tu fostes solto, foi...

Cosme - ... Aí ele aparece na janela...

Marinho - ... saiu a fotografia, na primeira página do "Jornal do Comércio”. É interessante dar esse depoimento: parece que já era o Danilo Areosa o governador. Então surgiu a idéia do Festival e eu levei a idéia ao Danilo. Disse: "Governador, vou fazer um festival". Ele disse: "Isso é coisa de comunista!" Mas, com toda aquela parcimônia que ele tinha, ele apoiava qualquer coisa que se realizasse em termos de cultura, porque, apesar de não ser um intelectual como era o Arthur Reis, dava apoio e deu apoios incríveis. E ele disse assim: "Quem vais convidar?", "Bom, vamos convidar o Cosme e o Márcio". "Esses dois estão presos". "Não, estão acabando de sair da prisão". E o interessante é que os dois saíram juntos e a fotografia que se apanhou dos dois saindo do Constellation, no aeroporto, estou eu no meio do Cosme e do Márcio. E isso sai no dia seguinte no jornal. O Danilo me chama ao Palácio no dia seguinte e diz: "Não tenho mais nada a ver com isso. Vais preso junto com eles na volta” (risadas). Mas, deu um apoio incrível ao Festival, numa época dificílima de conseguir qualquer coisa... Enfim, gerou aquela primeira reunião...

\section{"Então a gente descobriu Silvino Santos e descobrimos que o cinema existia no Amazonas desde a década de $10 "$}

Cosme -- Então, naquela primeira reunião que foi realizada no jardim de casa, o Joaquim estava lá, acho que estava todo mundo lá ...

Marinho-É, tava o Gaspar, que era o organizador da época, depois foi substituído. Cosme - Aí, aparece meu pai na janela, de pijama, nunca esqueço isso, ficávamos discutindo até altas horas da noite, e disse: "Vocês deviam era procurar o Silvino Santos, um português que fez cinema aqui na década de 20 e ninguém fala dele”. Eu que nunca tinha ouvido falar em Silvino Santos! - "Quem é Silvino Santos?”. "Ele é

128 Somanlu, ano 7, n. especial 2007 
funcionário do J. G. Araújo”. No dia seguinte estavam a Miriam Alencar, o Fabiano Canossa... A Miriam era crítica de cinema do Rio, na época trabalhava no "Jornal do Brasil". No dia seguinte fomos à caça de Silvino Santos. Encontramos o Silvino num canto de garagem de um prédio do J. G., na rua Isabel, onde havia montado um escritoriozinho, onde havia vários rolos de filmes, máquinas que ele mesmo tinha construído na década de 20, e fomos conversar com ele, inclusive uma conversa que foi gravada. Na conversa com ele estava o Geraldo Mayrink, naquela época crítico de cinema de Minas, que deu a maior cobertura. Foi o Marinho, foi o Gaspar, foi a Selda ...

Selda - Eu, não!

Cosme - Não, você não, foi o Roberto Kahané, Márcio e o Gaspar. Isso está até registrado em fotografia. Foi a grande descoberta do Silvino Santos... (Marinho tece comentários sobre a foto, quando eram todos magros e jovens). Tirou-se várias fotografias. Agora, não me lembro quem as tirou...

Selda - A Miriam Alencar. Ela tem os negativos e me mandou.

Cosme - O que eu sei é que até hoje a gente tem na Cinemateca várias fotografias. E uma foto famosa que está o Silvino Santos desenrolando um rolo de filme.

[Divagações ruidosas sobre fotos com artistas. Narciso observa que "Vai estourar essa fita"].

Bom, então a gente descobriu Silvino Santos e descobriu de repente que nós, inconscientemente, éramos parte de uma cadeia que tinha começado muito antes. Na verdade, nós não estávamos inventando cinema no Amazonas, mas que o cinema no Amazonas existia desde a década de 10 e, o que era mais impressionante, que não era só o Silvino Santos, como depois a gente veio a descobrir. Na verdade, a soma de informações que a gente tem hoje é ainda muito restrita a um pequeno grupo, nem nos ocorreu no momento... Existiu Silvino Santos e ponto final. O cinema no Amazonas, então, começou e acabou com Silvino Santos. E convidamos o Silvino para a sessão de encerramento. E nessa sessão, pena que não se gravou isso, o Silvino Santos, no palco do Cinema Odeon, falou sobre cinema brasileiro, denunciando o cinema estrangeiro que estava ocupando o espaço do cinema brasileiro! Selda - Um parêntese: saiu no O Cruzeiro o pronunciamento dele e algumas fotos. Marinho - E na $V e j a$, acho que ainda a tenho. Saiu uma fotografia do cartaz.

Cosme - O cinema estava lotado, não sei qual foi o filme do encerramento, "Macunaíma"? 
Marinho - Não, não foi "Macunaíma", foi o filme do Tarcisio Meira. "Macunaíma" foi o $3^{\circ}$ ou o $2^{\circ}$.

Cosme - Em suma,...

Marinho-Peraí, foi "A mulher de todos". [Confusão generalizada sobre o programa do Festival].

Cosme - Bom, mas então, a declaração do Silvino Santos foi um delírio. Eu me lembro que o cinema estava lotadíssimo...

Marinho - Ficou todo mundo aplaudindo de pé.

Selda - Ele falou o que todo mundo tinha vontade de falar e não podia falar...

Cosme - Não podia falar porque ainda estava no período repressivo.

Selda - Já estava!
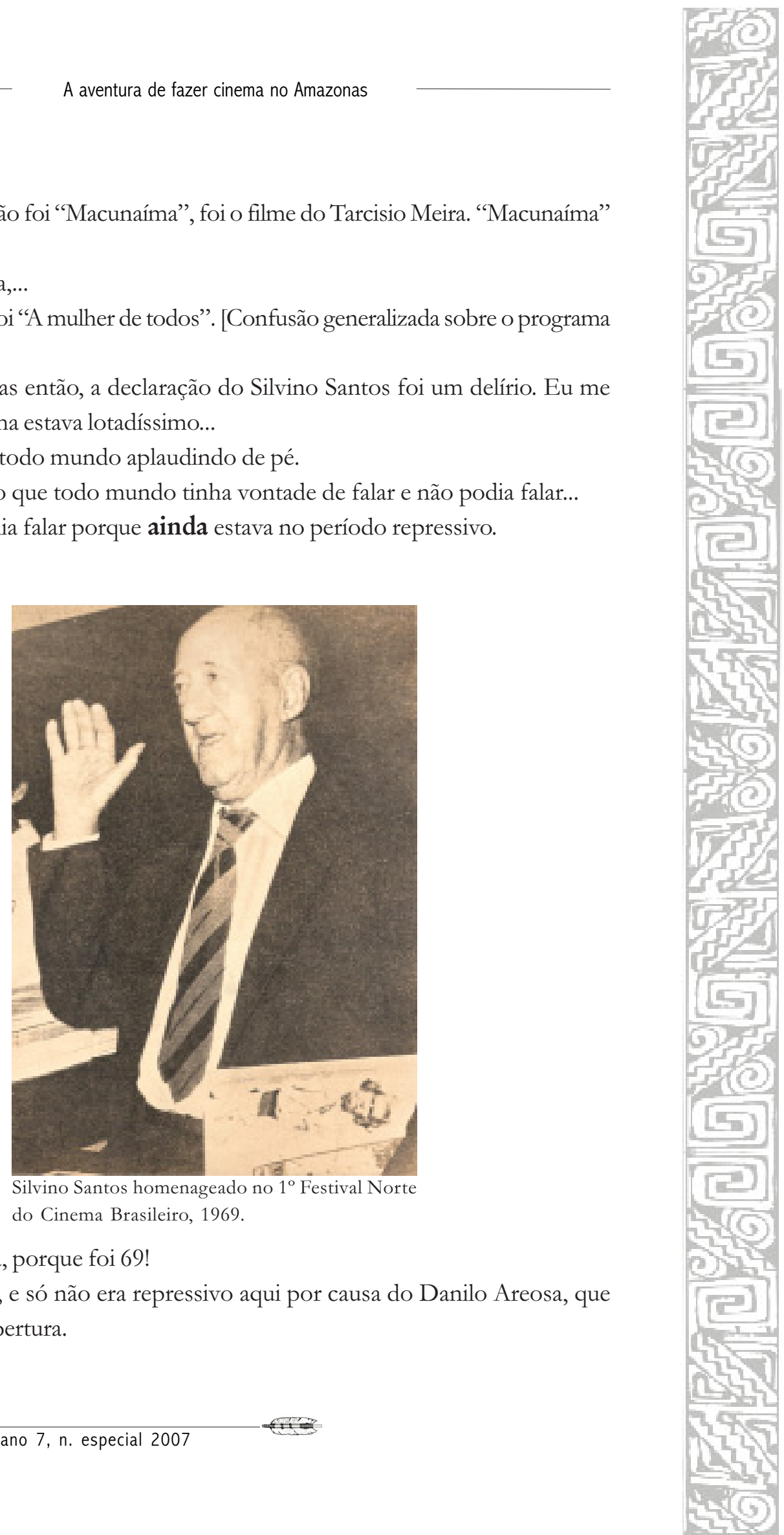

Cosme - Já estava, porque foi 69 !

Marinho - Exato, e só não era repressivo aqui por causa do Danilo Areosa, que resolveu dar essa abertura. 
Cosme Alves Netto

Cosme - O fato é que a declaração do Silvino Santos foi um delírio no cinema, ele foi embora para casa e um ano depois morreu.

Marinho - Não, dois anos depois...

Selda - Não, ele morreu em maio de 70. O Festival foi em outubro de 69, portanto, menos de um ano depois.

Cosme - Kahané e Demasi foram fazer um filme com ele e ele morreu durante as filmagens. [Comentários sobre o filme "Silvino Santos, o fim de um pioneiro"].

Cosme - Bom, mas aí entra o problema da memória. Nesse meio tempo eu já dirigia a Cinemateca e voltei pra Cinemateca preocupado em relação ao problema da memória cinematográfica, não só em Manaus, mas, evidentemente, em todo o Brasil. E foi o período que em São Paulo também se começou a preocupar muito com o problema da memória. O Paulo Emílio tinha uma preocupação com relação a isso e a gente começou a avançar na pesquisa da nossa memória cinematográfica. De repente, a gente parou de se preocupar com os filmes primitivos estrangeiros e a se preocupar com os filmes primitivos brasileiros. Foi a mudança, uma mudança assim de 90 graus no rumo da nossa preocupação. Paulo Emílio sempre tinha aquela frase famosa: O pior filme brasileiro tem mais a ver com nossa cultura que o melhor filme estrangeiro. Enfim, começamos a ver isso. Evidentemente que de lá pra cá, desde o começo de 70, uns 15 anos atrás, durante todo esse período, houve um crescimento da preocupação da pesquisa histórica do cinema, em especial do Amazonas, foi aí que apareceu a Selda...

Selda - Antes de mim, é bom lembrar que houve uma série de pessoas: o próprio Gaspar, que editou sua revista de cinema, "Cinéfilo", com circulação em bancas, que não tinha ainda preocupação de pesquisa, era mais artístico, com críticas, ensaios... Bom, antes de mim, é bom lembrar que houve Flávio Bittencourt que se preocupa, ainda como aluno da Universidade, em fazer um trabalho sobre Silvino Santos, e a gente esteve nesse projeto. Fez aquela exposição, em 1981, na Galeria de Artes Afrânio de Castro, e lançou outra vez a questão do Silvino Santos, com a exposição de fotos, máquinas e material dele, homenagem aos filhos... foi muito importante.

Cosme - A gente começa a descobrir, então, a nossa história. Através do interesse pelo cinema estrangeiro, pelo cinema de arte, pelo cinema comercial, começamos a descobrir a nossa história cinematográfica. Então, surge a pesquisa da Selda, surge a pesquisa do Flávio Bittencourt, a pesquisa do Gaspar... Algumas foram em frente, outras pararam. Gostaria, pra início dessa parte que eu vou falar, de ter como vinheta 
musical, que o nosso querido amigo Ivens reproduzisse o início do programa dele, como ele apresentava o programa na rádio.

\section{"O Festival de Cinema foi um momento divisor de águas. Uns foram para a realização cinematográfica, outros partiram para a pesquisa histórica"}

Ivens - Não lembro mais, rapaz, faz tantos anos... Bom, vai lá: "Senhores, mais uma vez muito bom dia. Estamos aqui pra apresentar Cinemascope no ar, o cinema em sua casa". Pronto!

Cosme - Isso aí vai ficar para a posteridade. Bom, eu vou retomar de onde eu parei. Estava dizendo, então, que o Festival de Cinema foi um momento divisor de águas, com o surgimento de dois caminhos complementares, no fenômeno cinematográfico amazonense. Nós temos, por um lado, as pessoas que começaram a se dedicar às diversas atividades na área de cinema: Márcio Souza, Domingos Demasi, Roberto Kahané que se especializaram, se dedicaram mais à realização cinematográfica, além de Djalma Batista, e a outra faixa que partiu para a pesquisa de nossa história cinematográfica: Ivens Lima, Selda Vale da Costa, eu mesmo, Flávio Bittencourt, e tinha mais dois nomes que você tinha citado (dirigindo-se para Selda)... Selda - Não, eu fui bem posterior ao Gaspar, que eu acho que começou um trabalho de pesquisa...

Ivens - O Marinho, que passou a explorar o povo...

Selda - ... como exibidor...

Cosme - E temos o Joaquim Marinho, que se dedicou à exibição cinematográfica. Ivens - Explorador do povo. Ele cobra dez mil o ingresso.

Cosme - Como!O Ivens não tem permanente?

Marinho - Não, entra de graça, o que é pior ainda. Entra, reclama e ainda leva a família toda lá pra cima, pra minha sala (risadas gerais). Em 1975, acabaram os cinemas em Manaus. Em 73,74... Em 74, só tinha um cinema em Manaus. Foi quando a gente assumiu a Fundação Cultural e então começou-se a pensar em montar um cinema. Um negócio interessante na parte da pesquisa, foi um negócio que cresceu muito até certa época e depois caiu de tal maneira com a Zona Franca... Aí acabaram os cinemas de Manaus. Acabaram. Ficou o Guarany, que era um pardieiro. A família Araújo derrubou o cinema, isso precisa ser colocado... Aí, então, o que aconteceu:

132 Somanlu, ano 7, n. especial 2007 

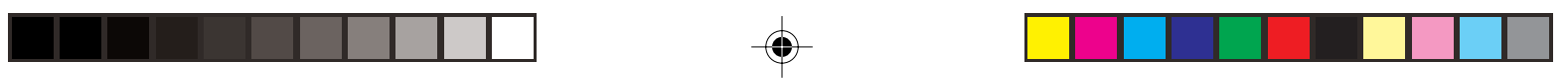

Cosme Alves Netto

ficou um cinema funcionando muito mal e porcamente e de uma hora para outra começaram a surgir outros. O Leong surgiu com o Cinema 2, foi o primeiro, já movimentado por uma idéia de cinema que a gente fez na Fundação Cultural, criando o Ciclo do Cinema Amazônico com a realização da produção do filme "Ajuricaba" e a tentativa de criar um cinema que fosse do Estado. Foi aí que surgiu o Cinema 2, que partiu do embrião de se fazer um cinema estatal. Foi a primeira idéia. Eu conversei com o Cosme sobre isso na época.

Cosme - Como a gente está vendo, então o Marinho fez o papel da $7^{\mathrm{a}}$ Cavalaria. Chegou para salvar dos índios os cinemas em Manaus.

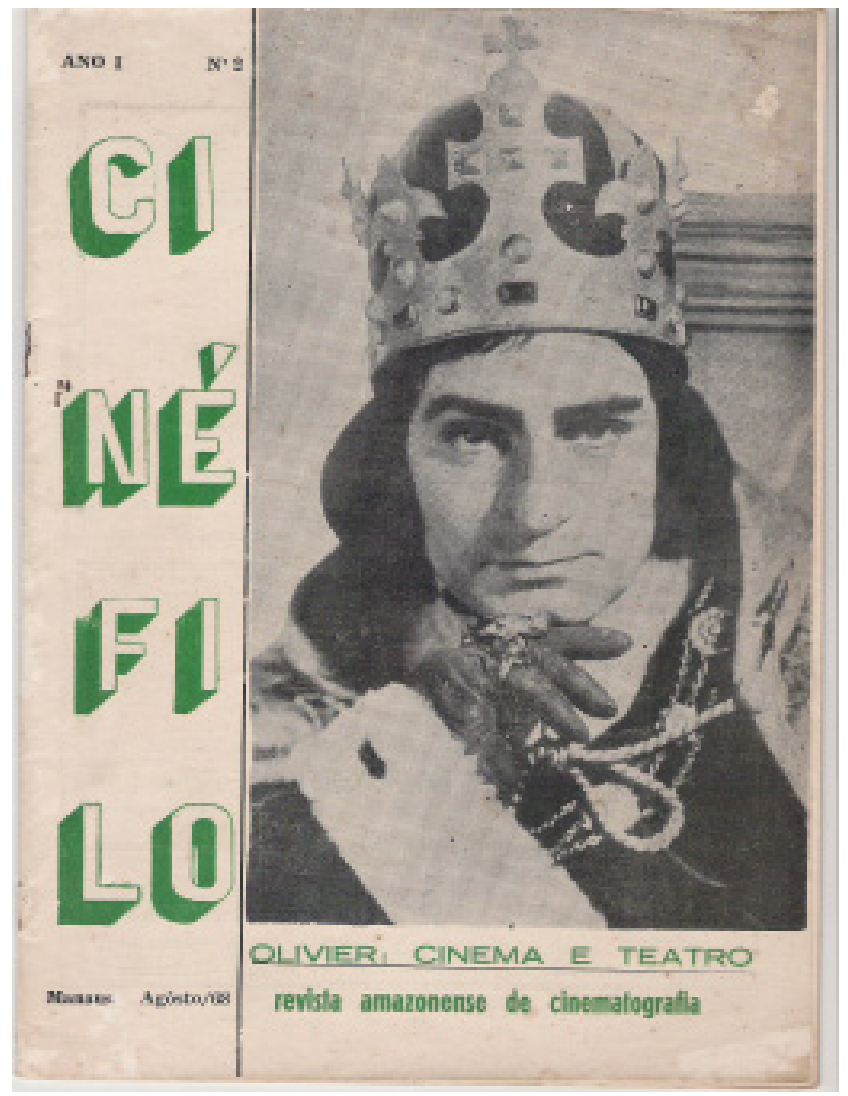

Primeira revista amazonense de ensaio e crítica cinematográficas, editada por José Gaspar.

Marinho - Não fui eu, não. O primeiro cara que fez um cinema aqui em Manaus depois dessa época foi o Leong. Ele topou a idéia que a gente tinha na Fundação 
Cultural, que não se conseguiu fazer por falta de definição do Tribunal de Contas, de se comprar um equipamento e montar um cinema, onde é agora o Cinema 2. O Leong surgiu querendo fazer um investimento em alguma coisa e como a Fundação tinha já pronto o contrato de aluguel daquele prédio, então, foi entregue ao Leong e ele fez o cinema. Ele foi realmente o iniciador dessa nova fase do cinema.

Cosme - Muito bem. O Leong é aquele cara que exibia os filmes com a luz acesa? Marinho-Isso!

Cosme -É, exibia os filmes com luz acesa no cinema. O Leong interpretou aquele filme "Guerrilheiro das Filipinas" (risadas). Continuando, então: teve uma vertente que foram as pessoas que se dedicaram à realização e à exibição e tem outra vertente, que são as que se dedicaram à pesquisa, como Ivens Lima, que já pesquisava antes e continuou pesquisando; depois vieram a Selda, eu mesmo, o próprio Gaspar e, "off-the records", o Joaquim Marinho... Então, o problema da pesquisa aqui: a descoberta do Silvino Santos mexeu com a cabeça da gente e despertou o desejo de verificar e estudar um pouco a história do cinema no Amazonas. Ao longo dos últimos 15 anos, essa história foi pesquisada e revelou alguns dados muito interessantes: os primeiros a se preocuparem com o cinema não tínhamos sido nós, mas o cinema já existia no Amazonas desde a década de 10 e esses realizadores cinematográficos, então absolutamente desconhecidos, não se resumiam a Silvino Santos. A descoberta do Silvino foi um acontecimento, mas ao longo da pesquisa, nós descobrimos outros nomes importantes também e material cinematográfico cada vez mais numeroso.

Selda - Só uma ressalva: se Silvino Santos não é o único nome, é, pelo menos, o nome que, residindo no Amazonas, fez o cinema aqui. Os demais, como você vai mostrar, é gente que aqui veio e esporadicamente fez filmes aqui.

Cosme - É verdade. O Silvino Santos seria o pioneiro amazonense realmente. Os outros são pioneiros do cinema que fizeram filmes no Amazonas. Então, eu vou, pra efeito de registro, enumerar as diversas fontes desse cinema, acrescentando desde logo que o projeto estabelecido pela Cinemateca, há mais ou menos cinco anos atrás, o "Projeto Filho Pródigo", pretendia fazer retornar ao Brasil o que foi filmado aqui no Brasil na década de 10 e 20 e que foi para o exterior, ou filmes feitos por brasileiros que estavam no exterior. Inclusive, uma das primeiras descobertas entra exatamente dentro do material localizado do Silvino Santos, que é o filme "No rastro do Eldorado", que se constitui basicamente no registro da Expedição Rice, que em 1924 percorreu o interior do Amazonas, levando o Silvino como seu

134 Somanlu, ano 7, n. especial 2007 
Cosme Alves Netto

cinegrafista. Esse filme, que desapareceu do Brasil, foi recentemente localizado pela Selda na Inglaterra, na Cinemateca inglesa, e a sua restauração já está sendo providenciada. Então, nós temos o primeiro lote Silvino Santos. O que se encontrou feito por Silvino no Brasil e Portugal já está em grande parte catalogado, localizado e em processo de restauração, graças a um projeto comum desenvolvido entre o Ministério da Cultura - Embrafilme, as cinematecas de São Paulo e do Rio e a Cinemateca Portuguesa. Esse material será objeto de uma restauração integral, tendo em vista não apenas a conservação definitiva dos filmes do Silvino, mas a organização de uma exposição itinerante em comemoração ao centenário de Silvino Santos, que se celebra a 29 de novembro deste ano. A idéia seria apresentar no dia 29, aqui em Manaus, a grande retrospectiva e a grande exposição de fotografias de Silvino Santos e essa mostra seria também levada a vários pontos do Brasil.

Em segundo lugar, nós temos o lote do Major Thomaz Reis. Era o cinegrafista do Rondon. O Rondon mandou o Major à França, na década de 10, para aprender a manipular uma câmera de filmagem. O Major foi a Paris, estagiou nos estúdios de Charles Pathé, que era então o grande fabricante de equipamentos cinematográficos, trouxe esse equipamento para o Brasil, acompanhou Rondon e é responsável por uma filmografia ainda não estabelecida quantitativamente, mas grande parte dela foi feita na região amazônica. O que sobrou do material do Major Thomaz Reis já está sendo restaurado, inclusive com o acréscimo de que um lote desses filmes foi localizado recentemente em Manaus, em poder do neto de Rondon, que vive aqui, e que está sendo entregue à Cinemateca para que se inicie imediatamente o processo de restauração e copiagem.

O terceiro lote, nós podemos considerar o que foi localizado na Biblioteca do Congresso, em Washington; se constitui basicamente do material filmado durante a Expedição de Theodor Roosevelt ao Amazonas, em 1914. Essa expedição trouxe o cinegrafista Diott, que acompanhou Roosevelt e realizou um longa-metragem, com mais de duas horas, que se chamou "Viagem ao Rio da Dúvida", já que Roosevelt estava procurando as cabeceiras do rio Amazonas. Esse filme inclusive registra, de acordo com a documentação que nós já temos sobre ele, entre outras coisas, o encontro entre Roosevelt e Rondon aqui no Amazonas. Esse material já está restaurado e sendo encaminhado ao Brasil pela Biblioteca do Congresso.

O quarto lote foi localizado na Cinemateca da República Democrática Alemã. Esse lote constitui cerca de 40 latas de filmes, filmados no Brasil e, a sua 
maioria, na região amazônica. Evidentemente que há filmes sobre a colonização alemã em Santa Catarina e no Rio Grande do Sul, mas a maior parte desses filmes se refere a filmagens feitas durante a vinda ao Amazonas de expedições alemãs, que vinham sempre com seus cinegrafistas, cujos nomes não foram identificados até o momento, mas que levavam o material filmado não necessariamente montado em forma de filme acabado, mas, enfim, material filmado que foi conservado pela Cinemateca da RDA. Uma parte desses filmes já está em poder da Cinemateca do Rio para sua restauração. A outra parte será entregue, dentro de alguns dias, em Brasília, à Cinemateca, para os efeitos de catalogação e classificação. É possível, inclusive, que no meio desses filmes haja mais material de Silvino Santos. É uma questão que os pesquisadores vão esclarecer muito proximamente.

O quinto lote é o material filmado, encontrado em algumas instituições norte-americanas, como o Instituto Smithsonian, material que nós não sabemos ainda exatamente o que é, mas é um material que já está sendo doado para nós por essas instituições.

E, finalmente, num período mais recente, nós temos o material filmado pelo Nunes Pereira. Depois da morte dele, que faz um ano, a família entregou esse material à Cinemateca (parte dele já tinha sido entregue à Cinemateca pelo Nunes Pereira em vida). É o resultado da atividade amadorística do Nunes Pereira, com a câmera cinematográfica $16 \mathrm{~mm}$, na qual ele registrou uma enorme quantidade de contatos com índios, enfim, todo o trabalho que ele executou durante anos de pesquisa na região amazônica. Evidentemente que nós temos também uma série de documentos esparsos, como os firmes feitos pelo Noel Nutels, que estão em período de restauração. Noel Nutels é um sanitarista famoso no Brasil que trabalhou muito com os índios. Nós temos algum material isolado que pode ter sido feito por cinegrafistas americanos ou europeus e está em fase ainda de pesquisas. Até mesmo cinegrafistas suecos ou noruegueses, feitos ainda na década de 20 no Brasil. Eu tenho a impressão de que com o levantamento de todo esse material, com o processo de restauração que está sendo empreendido pelo Pró-Memória do MINC, através da Embrafilme e das Cinematecas do Rio e de S. Paulo, além de uma série de outras instituições ligadas à cultura aqui no Amazonas e também da iniciativa privada, será possível nós termos em curto prazo uma amostra significativa daquilo que a gente poderia chamar de Memória Cinematográfica do Amazonas, que inclui filmes feitos por pessoas do Amazonas e por, digamos, cinegrafistas visitantes. Esse levantamento e essa restauração

136 Somanlu, ano 7, n. especial 2007 
permitirão colocar à disposição dos pesquisadores - não especificamente de cinema, mas aos sociólogos, aos antropólogos - uma documentação bastante valiosa que será certamente de utilidade nestas pesquisas.

Narciso - Quais as probabilidades desse material aparecer aqui pelo Amazonas?

Cosme - Na verdade, o que vai ficar concentrado no Rio e em São Paulo são as matrizes e esse material, ou seja, o resultante do trabalho técnico de restauração. Essas matrizes têm que ser conservadas dentro de certas condições técnicas que não são encontráveis com facilidade aqui no Amazonas, mas que existem, por exemplo, nos arquivos de filmes do Rio e de São Paulo. A Cinemateca já trabalha com esse tipo de material. Mas, a idéia seria que, de todo esse material, fossem tiradas as cópias e essas cópias viessem para o Amazonas, fossem entregues a uma instituição do Estado, ainda não definida, e ficassem permanentemente aqui. $O$ fato das matrizes serem conservadas em temperaturas baixas e em condições de umidade específicas vai permitir que as cópias retiradas e vindas para Manaus possam ser utilizadas sem qualquer problema, porque na medida em que, com o uso, elas forem sendo gastas, deterioradas, existe sempre a possibilidade de serem retiradas novas cópias das matrizes que ficarão arquivadas nas cinematecas do Rio e de São Paulo. Falta definir qual seria a instituição amazonense que receberia essa coleção de filmes. Essa definição não vai depender de nós, vai depender muito do Estado do Amazonas, das forças produtivas do Amazonas, das forças culturais do Amazonas.

\section{"As pessoas me colocam, estranhando: Por que uma antropóloga mexendo com cinema? Quê que é isso?!"}

Narciso - É aqui que se coloca: como a gente vai resolver essa questão de se ter uma memória cinematográfica do Amazonas aqui no Amazonas, e de que forma? Selda-O mais importante talvez seja desencadear uma campanha, basicamente em Manaus, para sensibilizar não só organismos estatais, mas até a Universidade, os Departamentos dentro da Universidade e outras instituições culturais, para que se perceba esse material não apenas como diversão, cinema como material de ficção ou qualquer coisa assim. Eu acho que o Cosme já falou que esse material é fundamental para a pesquisa histórica no Amazonas. Nós temos que mudar um pouco essa nossa idéia de que fazer história é apenas em cima de documentos escritos. 
Temos que acabar um pouco com esse domínio da escrita, como única verdade para se fazer história. Eu acho que o material visual tem que começar a ser visto como algo fundamental para se fazer e reconstituir uma história, como a música, a arquitetura, a literatura, que são fontes fundamentais para se reconstituir uma história e se ter uma memória de uma região, de uma época, de um momento, do presente, inclusive. Se a gente conseguisse sensibilizar os intelectuais amazonenses, eu acho que a gente poderia, a partir dessa sensibilização, conseguir com que se perceba a importância desse material e se reúnam certos esforços. Porque senão fica assim: "não, cinema é com o pessoal lá de Comunicação, cinema é com o pessoal lá dos exibidores, cinema é com o Departamento sei lá do quê do Estado". Esse material que está sendo redescoberto, agora, que não é bem descoberto, mas redescoberto, ele tem que ser visto como documento histórico. Até a Cedeam (Comissão de Documentação e Estudos da Amazônia), por exemplo, da Universidade, podia ser um local para se recuperar: não se está microfilmando documentos da época colonial? Por que não recolher o material, em termos visuais, da História do Amazonas? Quer dizer, isso é uma questão que a gente tem que discutir, eu sinto isso, como antropóloga, quando as pessoas me colocam: "Por que uma antropóloga mexendo com cinema? Que é que é isso? Cinema é lá com o Departamento de Comunicação”, entende? Narciso - Como a gente vai viabilizar essa questão? O Ivens tem lá na casa dele praticamente um museu, dentro da indústria cultural - discos, quadrinhos, filmes etc. - como é que a gente vai viabilizar esse material todo numa instituição que mereça confiança para os doadores? Porque deve existir muita coisa nos baús: fotografias, muito material em casa de pessoas, que irá aparecer... Assim como apareceu esse material do neto do Rondon. Fica o desafio: temos, agora, possibilidade de ter cópia desse material como o Cosme falou. E agora, como vai ser: guardar aonde, exibir aonde, e confiar a quem?

Selda - A minha experiência em Manaus é meio pessimista. Talvez eu não seja a melhor pessoa para estar dando opiniões a respeito disso. Eu acho que, em nível de Estado, infelizmente a gente tem que confessar, a sensibilização para esse tipo de preocupação de resgatar a memória visual do Amazonas tem sido mínima. Parece que cultura neste Estado é considerada como algo supérfluo, algo que não é prioritário. A gente tem visto tentativas como o Museu da Cidade que está aí parado, se destruindo o pouco que foi conseguido em governos anteriores, que poderia ter sido um local não só para montar salas de exibição, de exposições, de trabalhos de criatividade

138 Somanlu, ano 7, n. especial 2007 
artística, mas, sei lá, pensar em outras coisas que pudessem ser realizadas nesse espaço. Não houve. Nós temos agora a Superintendência Cultural. É fundamental que se diga que o Silvino Santos não só foi o pioneiro do cinema no Amazonas, mas foi um dos pioneiros da fotografia, com outras casas fotográficas, como a Fidanza, a Lira, a Fotografia Alemã, cujo material está se perdendo. O Silvino tem negativos impressos em vidro, que era o processo anterior ao do celulóide, que estão aí se perdendo na Superintendência Cultural. Das duas mil chapas, hoje não resta nem metade, não se sabe por onde é que andam e o que é que vão fazer das que sobraram. O material que está na Associação Comercial também precisa ser recuperado; são máquinas fotográficas que estão sendo descobertas, máquinas antigas do Lumière, de fole. Tem gente aí querendo doar, querendo vender, pra quem? Eu acho que, por parte do Estado, tem havido pouca preocupação em relação a isso. Infelizmente, já que outros têm mostrado uma sensibilidade dos governos. Isso aí é fundamental para o patrimônio, para a memória e para a identidade do Estado, identidade nacional etc.

Eu acho que se o Estado do Amazonas não assume essa preocupação de resgatar a memória, inclusive com essas facilidades de doações particulares, acho que nós temos que partir para outras formas, entidades outras que não sejam governamentais. Penso que Estado deveria assumir isso, é obrigação do Estado, mas se o Estado não assume, tem a fundação Joaquim Nabuco, com o Museu do Homem do Norte, que apesar da falta de verba pode, como fundação, conseguir recursos no Pró-Memória, ou em outros locais. Talvez a gente tenha que tentar essa instituição, porque fora disso eu não vejo aonde, no Amazonas. Nós corremos o perigo de estar descobrindo coisas, estimulando gente a descobrir e a trazer até nós o material e a gente acabar tendo que perder esse material por falta de uma instituição que possa realmente, não só guardar, recuperar, mas também exibir. Tornar público isso aí, levar para estudantes, levar para discussões, mostrar o que se produzia nesta terra e o que se pode conhecer dessa terra através do visual.

Narciso -É importante que ouçamos o Ivens, apontado como pessimista, e depois o Marinho, que é um bem sucedido empresário de cinema, se manifestasse sobre essa questão. Eu gostaria de ouvir o Ivens, como pesquisador, que se apaixonou pelo cinema, via cinema estrangeiro, sem saber que na sua terra já havia uma tradição de cinema, e depois, com muita satisfação, veio a descobrir que havia uma história. Isso foi uma surpresa muito grande para essa geração toda. 
Ivens - Inicialmente, acho difícil. Não acredito, acho muito difícil que um dia nós tenhamos pelo menos uma casa onde se possa guardar esse material, que dia a dia está perecendo, devido a um dos maiores inimigos que são as condições climáticas que nós temos. Um dia temos um sol de 35 a 40 graus e no outro temos um dia de chuva, que provoca queda brusca de temperatura e isso prejudica sensivelmente todo e qualquer material cinematográfico. Por outro lado, a respeito do material de história em quadrinhos, que é uma outra coisa que eu guardo, curto, temos o mesmo problema, que é a umidade. E em $3^{\circ}$ lugar, a parte de música popular, devido o grande material que eu tenho, de disco e essas coisas todas, nós estamos sentindo que dia a dia - já é uma preocupação minha - falta espaço, falta dinheiro e faltam condições para manter e conservar isso. Acima de qualquer coisa eu sou honesto e digo para vocês todos: eu não acredito; é preciso que seja realmente alguém de muita responsabilidade, que venha amanhã ou depois pleitear esse material que é meu, de minha propriedade e também que eu esteja num dia de estado de graça para entregar esse material, que eu guardo dentro de minha casa, para alguém tomar conta dele. Porque eu acho muito difícil. Se eu, na minha casa, que amo, que gosto, que pesquiso, que gasto dinheiro do meu bolso, enfrento uma série de dificuldades, imagine isso entregue a alguém ou a uma repartição pública! Eu vou morrer! Primeiro eu vou ter que morrer para depois então tomarem conta. Porque, honestamente, eu não acredito que em nossos dias nós tenhamos alguém ou uma casa ou uma instituição que tenha capacidade para guardar e conseguir organizar.

Cosme - Antes do Marinho, eu só queria dar uma complementação ao depoimento do Ivens, que é o seguinte: na verdade, o que a história mostrou é que o que se salvou se salvou graças à dedicação de particulares e não por causa de preocupação de instituições de Estado. Tudo o que se salvou do Rondon, do Silvino Santos, do Major Reis, enfim, de todos esses cineastas que trabalharam na região amazônica, se salvou por causa de interesses particulares, privados, de pessoas que se preocuparam em guardar, não necessariamente por causa do Estado. Na verdade, o Estado se preocupa muito com a memória escrita. Você vai ao município mais longínquo do Amazonas e você vai encontrar o arquivo municipal abarrotado de papel, mas ninguém se preocupou em guardar imagens.

Ivens - Sem controle, sem controle...

Cosme - Sem controle, mas de qualquer maneira guarda-se tudo. É bom guardar tudo...

$140 \quad$ Somanlu, ano 7, n. especial 2007 
Ivens - É um depósito...

Cosme - É um depósito. Eu acho que essa preocupação com a imagem, e particularmente com a imagem em movimento que nos diz respeito aqui, é uma preocupação muito recente por parte do Estado. E quase nunca com continuidade. $\mathrm{Eu}$ acho que a gente tem todo o direito de ser pessimista, mas eu acho que a gente tem que encontrar uma solução. Há varias soluções: uma delas é por que não criar uma fundação de direito privado, uma fundação não do Estado? Essa fundação poderia ser criada. A lei de fundações permite que se crie esse tipo de fundação, que ficaria entregue aos particulares que se preocupam com isso. A outra solução seria eventualmente um contrato de comodato com o Estado, pelo qual a propriedade desse material permaneceria com os particulares. Bom, isso foi apenas uma complementação ao que o Ivens disse. Eu passo ao Marinho para encerrar com fecho de ouro essa brilhante série de intervenções.

\section{"E nós ficamos numa cidade para viver única e exclusivamente em função do asfalto. Cadê nossa memória histórica? Cadê nossa identidade cultural com a selva?"}

Marinho - A melhor solução realmente é essa entidade de direito privado. Poderia ser anexada a alguma associação de classe e que não dependesse das mudanças climáticas de governos, de quatro em quatro anos, ou de 20 anos, a gente não sabe o que virá por aí depois. E esse problema de a gente ter de quatro em quatro anos, ciclicamente, um governador que adora cultura, um governador que detesta cultura, a gente fica sempre dependendo da boa vontade ou da ligação que ele tenha com as coisas culturais ou não culturais. O grande problema é que o que existe hoje - e isso tanto o Cosme como o Ivens disseram - existe em função dos particulares. Na hora que surge o dinheiro - e recentemente o caso aconteceu com o Guarany - acabou a idéia de preservar alguma coisa. O próprio Teatro Amazonas agora vem de uma fase das mais negras de sua vida, onde até placas comemorativas de Natal em prol de entidades governamentais se colocou em frente do Teatro desvirtuando estupidamente um monumento público. Amanhã, vai se querer colocar uma coroa de louros no Monumento à Abertura dos Portos ou nalgum busto de Eduardo Ribeiro que exista por aí e o pessoal não vai dizer nada, porque ninguém respeita absolutamente nada do Estado, porque a parte histórica é coisa de maluco, de um

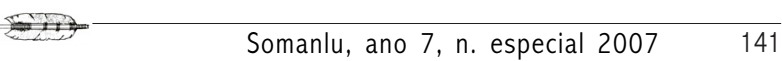


bando de alucinados ou de velhos esclerosados. Eu ainda sou a favor da maluqueira individualista. O Ivens tem as suas coisas. A gente se entendeu - apesar de sempre termos idéias bastante diferentes sobre uma série de coisas - mas a gente se entende, cada um vai guardando as suas coisas. Eu arranjo pro Ivens fotografias antigas ou filmes antigos ou alguma coisa que ele guarda com mais carinho do que eu - ou tem condições de guardar - e isso vai passando, aos pouquinhos a gente vai guardando essas coisas. Hoje o Ivens deve ter uma memória histórica a respeito do cinema talvez das mais espetaculares do Brasil inteiro e essa memória está guardada porque está na mão dele.

No Brasil existe a Cinemateca Brasileira e a Cinemateca do MAM, mas nem o MIS tem condições de preservar, de guardar tudo isso. Porque os próprios dirigentes do MIS, que não são como os da Cinemateca, quase que liquidaram o patrimônio do Museu. Então, se se pensou em criar um MIS em Manaus, eu acho uma loucura, porque será mais um museu da imagem e do som sem poder ir para frente. Onde se vão guardar as coisas aqui em Manaus que poderiam ficar em mãos de particulares $\mathrm{e}$, às vezes com mais cuidado, mesmo tendo algumas coisas se estragando? Entregar, por exemplo, para o Museu do Homem do Norte, ou para o Museu do Porto, que é uma entidade já um pouco mais responsável, porque depende de uma verba federal? Talvez aí fosse uma boa solução, mas essas coisas vão sempre cair no lugar comum: é praticamente irresponsável a presença da autoridade estatal como uma preservadora das coisas históricas. Recentemente, tivemos um exemplo brutal disso - a Comissão do Patrimônio Histórico da cidade de Manaus, que autorizou a destruição do Cinema Guarany. Você foi testemunha ocular de tudo isso. Foi o presidente do Patrimônio Histórico do Estado que autorizou, através de uma assinatura num ofício, a destruição do Guarany, como não sendo um prédio histórico ou de algum valor para a memória da cidade de Manaus. Então, essas coisas acontecem. E acontecem exatamente em função do volume de dinheiro que se vai utilizar para um negócio desse. Amanhã, se aparece alguém que resolva achar que o rio Negro não é importante para nós e resolver aterrar o rio Negro, se tiver dinheiro, aterra. $\mathrm{O}$ mesmo com os igarapés. E nós ficamos numa cidade para viver única e exclusivamente em função do asfalto. Cadê a nossa memória histórica ou nossa identidade cultural com a selva? Essas coisas todas não são pessimistas, são da realidade que a gente está sentindo no dia a dia. Vem um prefeito e liquida com todas as árvores porque ele acha que é mais importante o automóvel e o asfalto, para liberar

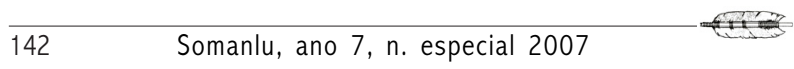


o trânsito e poder transformar a cidade numa cidade moderna, do que manter a identidade histórica, a identidade cultural, a identidade florestal da gente. Amanhã vem um outro e resolve fechar todos os igarapés de Manaus porque ele acha que igarapé é foco de poluição, é foco de casebre e cidade flutuante. Aí fecha todos os igarapés e transforma tudo em grandes avenidas. Surgirá um novo Eduardo Ribeiro... Então, essas coisas estão no dia-a-dia da gente. A gente está vendo isso acontecer. Sugeriu-se que a floresta amazônica tem que ser domesticada, tem que ser civilizada, e a gente vê que a partir daí o guardar um papel com a criação da cidade de Manaus é uma imbecilidade, que não tem valor nenhum, porque vai surgir nesse lugar um prédio de 20 andares. Isso não é nem pessimismo, é a realidade. Isso é o dia-a-dia que a gente está vendo. Eu ainda acho que o individualismo nessa parte é muito importante. As grandes coleções de arte do Brasil ficaram em mãos particulares e hoje existem porque foram preservadas por particulares, o que é uma tristeza, mas nós somos um país sul-americano, latino-americano, cheio de sofrimentos e problemas muitos sérios.

Narciso - Eu gostaria de ouvir o Cosme, saber o que ele nos diria, com toda a sua experiência, sua vivência e o duplo sentido de sua presença aqui, como amazonense e como conservador de cinemateca.

\section{"O Ministro da Cultura já se convenceu de que filme antigo tem tanto valor quanto um monumento antigo. Ambos são testemunhos históricos"}

Cosme - Eu tiro várias conclusões dessa conversa aqui. A primeira conclusão é que fica evidente, fica patente que, digamos, essa nova vocação cinematográfica amazônica na época moderna, nossa, individual, ela começou com o Ivens. Historicamente, o Ivens foi o primeiro. Agora, como o cinema entrou na cabeça da gente é toda uma outra história. Nós somos filhos do Ivens... Em segundo lugar, eu não sou tão cético quanto vocês quanto à participação do Estado, porque eu acho que você tem que fazer uma diferença entre a participação do governo federal e do governo estadual... Eu acho que o governo federal está dando demonstração de interesse objetivo com relação a essa conservação. Tanto é assim que eu estou aqui por conta de um órgão federal, que é a Embrafilme, que tem na direção, atualmente, o ex-conservador da Cinemateca de S. Paulo e tem na direção do setor cultural o ex-vice-diretor da 
Cinemateca do Rio, quer dizer, as cinematecas tomaram o poder cinematográfico, estão criando condições mais estáveis para a preservação dessa nossa memória cinematográfica. Evidentemente que o poder federal também é cambiável, mas eu acho que enquanto eles estão lá, eles podem criar condições objetivas, como estão criando, pelo menos para restaurar essa memória. Porque já liberaram as verbas. $\mathrm{O}$ José Carlos Avelar está lá há 4 ou 5 meses e já conseguiu liberar verbas para restauração de filmes, pesquisas etc., até mesmo o Boletim do Centro de Pesquisadores de Cinema vai ser financiado pela Embrafilme. A Embrafilme dá o dinheiro para o Boletim publicar todas as pesquisas individuais que os pesquisadores estão fazendo por conta própria. Em terceiro lugar, é evidente que o trabalho individual foi o que existiu e o que vai continuar existindo, não tenho a menor dúvida, na medida em que cada um for picado pela mosca da pesquisa, da conservação etc. e tal. Isso vai ser sempre assim. Eu acho que no caso específico do Amazonas é tentar realmente criar uma associação - não precisava nem ser uma fundação - uma sociedade civil sem fins lucrativos, qualquer coisa que garanta o seu controle na área privada e não na área do governo do Estado. Agora, como isso deve ser feito ou não, isso eu acho que vocês é que devem resolver. Eu acho que, inclusive, não há porque não criar uma comissão formada por pessoas que estão aqui e mais alguns, para encontrar soluções alternativas para o caso do Amazonas. Na verdade, embora a gente tenha começado todos juntos, a gente está trabalhando cada um mais ou menos individualmente na sua área. Então, eu acho que é o momento das pessoas se reunirem de novo (não recriar o GEC, isso é coisa do passado), mas tentar, em forma de comissão, estudar alternativas, inclusive com auxílio da empresa privada, que eu acho que é quem pode realmente fornecer recursos eventualmente. Tentar montar alguma coisa. Se não quer entregar ao Estado, montar alguma coisa particular, que tenha condições de sobrevivência, de permanência, que nunca saia do controle nosso. Marinho - "Plínio e Gilberto"... (cantando).

Cosme - Pois é, se o Gilberto [Mestrinho] me der amanhã um bilhão para restaurar filmes eu canto junto com ele a música. Eu não tenho o menor problema. Eu sou completamente corruptível nessa área (risos). Me dá um bilhão que eu canto junto com você a música. Não tem problema, mas restauro os filmes. Então, vocês têm que pensar em alguma coisa, têm que encontrar uma solução qualquer, não pode ficar na mesma depois de todo esse panorama rico de descobertas feitas, inclusive,

144 Somanlu, ano 7, n. especial 2007 
Cosme Alves Netto

por pessoas que não tem nada a ver com a memória amazônica, estão preocupados é com a memória em geral, com o problema do passado.

Ivens - Agora, um adendo: só para vocês terem uma idéia da posição que eu estou vivendo do meu trabalho, das minhas pesquisas. Eu tirava uma cópia xerografada e custava 300 cruzeiros uma redução ou ampliação, dependendo do fotograma, da minha necessidade. Pois bem, na semana seguinte, eu voltei lá e aumentaram de 300 cruzeiros uma redução ou uma ampliação para dois mil. E na semana passada eles resolveram dar uma mexida, de dois mil para quatro mil cruzeiros enquanto que a cópia xérox simples custa 500 cruzeiros. Quer dizer, numa terra dessas, a gente pode fazer um trabalho em prol da cultura? Não pode!

Cosme - Pois é, individualmente não pode, mas se você tiver uma associação, uma fundação, coisa que o valha, essa associação pode ter fundos para comprar uma xérox e ser utilizada pelos membros para fins de pesquisa.

Selda - Agora, Narciso, nós que somos da Universidade do Amazonas, eu acho que a gente deveria forçar um pouco a barra, porque a proposta do atual reitor [Roberto Vieira] é uma proposta de termos uma universidade amazônica. Eu acho que é importante ver até que ponto essa nova direção da Universidade realmente assume as propostas de sua campanha. Acho que é fundamental que a gente force um pouco essa Universidade. Eu sei que sou meio pessimista, meio cética em relação à nossa universidade, mas ...

Ivens - Quem é pessimista aqui sou eu, minha filha.

Selda - Não, eu sou cética. Não sei até que ponto a estrutura universitária, que ainda não foi quebrada, permite avançar um pouquinho esses projetos. De qualquer maneira, se a gente conseguisse mobilizar a Universidade, que é uma área que a gente poderia encontrar mais adeptos para isso, teríamos instituições governamentais federais, tipo Funarte e outras que estão aí, dispostas a financiar. É só fazer projetos que eles financiam. O que está faltando aqui no Amazonas, sei lá, é sensibilizar o pessoal pras coisas da terra. O pessoal tá colonizado demais aqui. Não sei se é por causa da Zona Franca ou que coisa que a colonização aqui. É preciso que venham pessoas de fora, tipo eu, que não nasci aqui, mas me sinto amazonense. A gente tá mexendo... Agora, cadê os amazonenses? Mesmo os antigos ou os novos... Onde é que está essa geração nova? Onde estão os estudantes? Eu acho que a Universidade é o campo onde a gente tem de mexer. Quem é que está disposto a isso? 
Cosme - Eu acho que uma das coisas que se poderia fazer realmente era chamar os caras que têm grana, da iniciativa particular, e colocar a proposta do Fundo. Eu não duvido que certas pessoas contribuiriam pra um fundo que seria gerido pela iniciativa privada, pela sociedade, pela fundação, sei lá o quê, para a preservação da memória. O próprio Estado pode participar desse fundo. Se for questão de dar dinheiro não tem problema. Eu acho que vocês deveriam se reunir depois e discutir esse problema. Tem que encontrar uma saída. Enquanto a saída não for encontrada, as matrizes estão sendo preservadas por lá. De qualquer maneira, acho que a gente já avançou muito. A cinco anos era muito pior do que agora, entende? De cinco anos pra cá houve a criação do Ministério da Cultura, que bem ou mal liberou verbas para a pesquisa e a conservação e que se convenceu de que filme velho tem o mesmo valor de documento e que se você tem que preservar monumentos, você tem que preservar filmes velhos porque os dois são testemunhos da história do Brasil. Então, disso eles já estão convencidos, quer dizer, a nível federal, eles já estão convencidos. Se eles não estivessem convencidos, não teriam me mandado aqui.

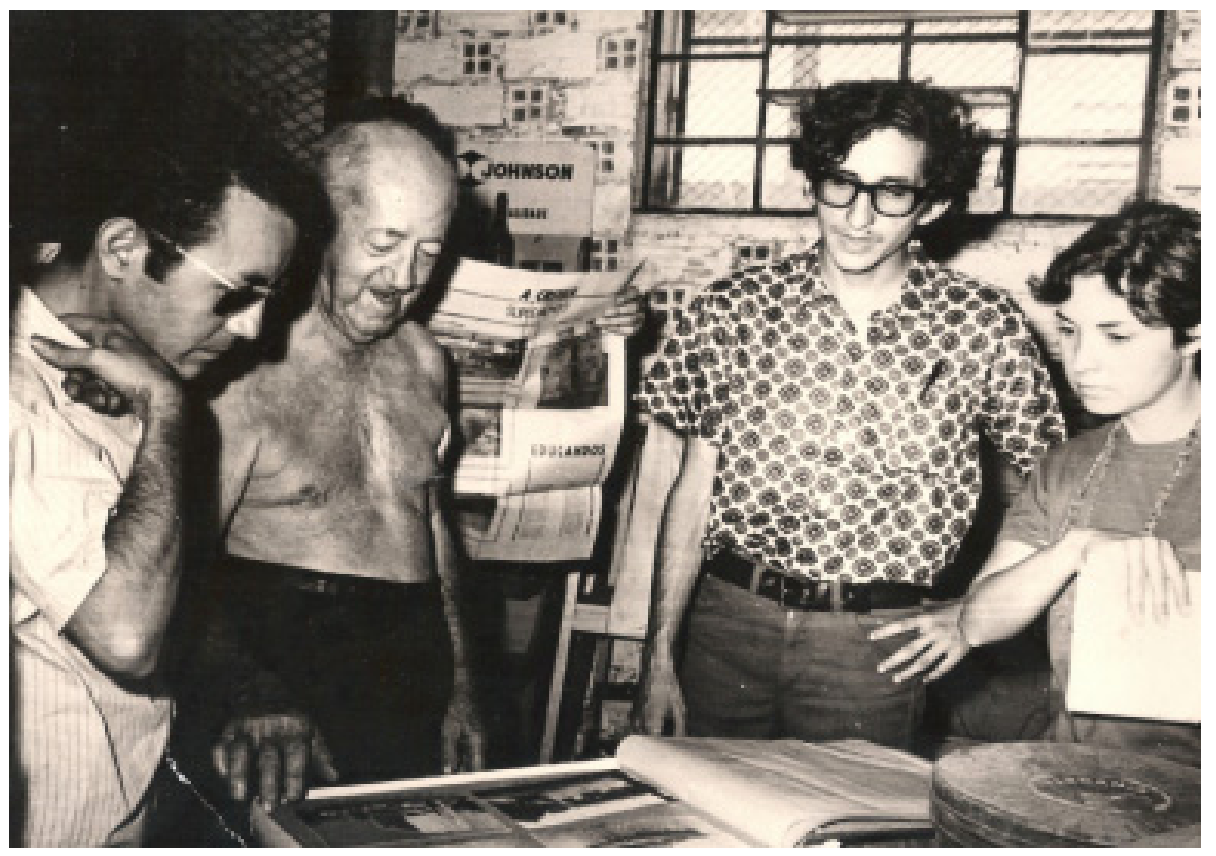

Silvino Santos, em outubro de 1969, mostra seus álbuns fotográficos e filmes a José Gaspar, Márcio Souza e Miriam Alencar (Acervo Selda Vale). 
Cosme Alves Netto

Ivens - Eu acredito que não só filme, Cosme, mas qualquer documento, qualquer fragmento de um trabalho, de um livro, de uma fotografia, de uma pintura, de uma escultura, é válido, desde que seja preservado.

Cosme - Concordo inteiramente, inclusive eu acho que a gente tem que encontrar até as máquinas que o Silvino usava e guardá-las.

Ivens - Vocês não sabem, e eu vou dizer: anos atrás, acredito que há uns 15 ou 20 anos atrás, me deram de graça os discos que foram rodados no cinema Avenida e no cinema Guarany, quando da sua inauguração. Através disso, consegui discos em 78 rotações, gravados no Brasil, ou melhor, prensados no Brasil no ano de 1902. Estão arquivados na minha casa para quem quiser ouvir...

Cosme - Perfeito. Tem que ser criada...

Ivens - Uma instituição?!... Entregar isso para uma instituição cultural?!!

Selda - Vocês querem um testemunho? Acabei de receber um telefonema da Margaret [Queiroz] que é a responsável pelo Museu do Porto, dizendo: “Selda, pelo amor de Deus, tem uns fotógrafos aí que estão com 3 ou 4 máquinas fotográficas antigas, não se sabe nem de que ano são, tipo Lumière, portátil, uma das primeiras portáteis, outra de fole, estão querendo vender, doar, pra comprar outras mais modernas" e Margaret está querendo comprar e está querendo saber que instituição pode ter isso. Quer dizer, aquela nossa idéia, de uns meses atrás, de um arquivo de música, cinema e fotografia, de a gente tentar no Museu do Homem do Norte ter um local para começar a guardar, pedindo as doações, depois exibir esse material em termos públicos e começar a trabalhá-lo, a preservá-lo, fazer um arquivo, pesquisa etc., quer dizer, a gente tem que levar essa idéia pra frente, seja no Museu do Homem do Norte, ou seja onde for, porque material existe nesta terra, e há gente querendo doar, inclusive o próprio Mário Ypiranga disse: “Eu dôo, mas pra quem?”. O Ivens é a mesma coisa. Esses fotógrafos que estão com essas máquinas antigas é a mesma coisa. E agora: para quem? Pra onde? A mesma coisa a Embrafilme pergunta: vamos fazer uma cópia de todos os filmes do Silvino para deixar numa instituição amazonense: qual? Eu acho um horror a gente se matar, ir até Londres pra descobrir a cópia de um filme, como eu fui, andar percorrendo esses lugares todos pra descobrir alguma coisa, pra não saber o que fazer com isso aqui no Amazonas. Senão a gente cai no perigo de mais uma vez isso ir para fora, pro Rio ou São Paulo e a gente ficar reclamando aqui: "Rio e S. Paulo têm tudo na mão e a gente não tem nada". E quando tem não sabe o que fazer com ele. 
Narciso - Pois é, esse é mais um capítulo da emocionante novela da cultura amazonense e se alguém quiser se manifestar, que se manifeste agora ou nunca mais (risos).

\section{Notas}

1 Albertino ficou por muito tempo dedicado ao conserto de aparelhos eletroeletrônicos. Já falecido.

${ }^{2}$ Hoje, Lojas Riachuelo. 